\title{
Article \\ Bacteriophages with Potential to Inactivate Aeromonas hydrophila
in Cockles: In Vitro and In Vivo Preliminary Studies
}

\author{
João Duarte (D), Carla Pereira (1), Pedro Costa and Adelaide Almeida *(1)
}

Department of Biology and CESAM, University of Aveiro, Campus Universitário de Santiago, 3810-193 Aveiro, Portugal; j.macedoduarte@ua.pt (J.D.); csgp@ua.pt (C.P.); pedrommrscosta@ua.pt (P.C.)

* Correspondence: aalmeida@ua.pt

Citation: Duarte, J.; Pereira, C.; Costa, P.; Almeida, A. Bacteriophages with Potential to Inactivate Aeromonas hydrophila in Cockles: In Vitro and In Vivo Preliminary Studies. Antibiotics 2021, 10, 710. https:// doi.org/10.3390/antibiotics10060710

Academic Editor: Marco

Maria D'Andrea

Received: 28 April 2021

Accepted: 9 June 2021

Published: 12 June 2021

Publisher's Note: MDPI stays neutral with regard to jurisdictional claims in published maps and institutional affiliations.

Copyright: (c) 2021 by the authors. Licensee MDPI, Basel, Switzerland. This article is an open access article distributed under the terms and conditions of the Creative Commons Attribution (CC BY) license (https:/ / creativecommons.org/licenses/by/ $4.0 /)$.

\begin{abstract}
The recurrent emergence of infection outbreaks associated with shellfish consumption is of extreme importance for public health. The present study investigated the potential application of phages AH-1, AH-4, and AH-5 to inactivate Aeromonas hydrophila, a causative agent of infections in humans associated with bivalve shellfish consumption. The inactivation of $A$. hydrophila was assessed in vitro, using a liquid culture medium, and in vivo, using artificially contaminated cockles with A. hydrophila ATCC 7966. In the in vitro experiments, all phages were effective against $A$. hydrophila, but phage AH-1 (with a maximum reduction of $7.7 \log$ colonies forming units CFU $/ \mathrm{mL}$ ) was more effective than phages $\mathrm{AH}-4$ and $\mathrm{AH}-5$ (with reductions of 4.9 and $4.5 \log \mathrm{CFU} / \mathrm{mL}$, respectively). The cocktails AH-1/AH-4, AH-1/AH-5, AH-4/AH-5, and AH-1/AH-4/AH-5 were slightly more effective than the single phage suspensions. The phages presented a low emergence rate of phageresistant mutants. When artificially contaminated cockles were treated in static seawater with phage AH-1, around $44 \%$ of the added A. hydrophila (1.0 log CFU/g) was inactivated. The results of this study suggest that phage therapy can be an effective alternative to control human pathogenic bacteria during depuration.
\end{abstract}

Keywords: Aeromonas hydrophila; bacteriophages; phage therapy; Cerastoderma edule; depuration; food safety

\section{Introduction}

Bivalves are an essential part of the human diet, and their commercial value continues to increase worldwide [1]. In 2018, world production of aquaculture bivalves reached 17.7 million tonnes [2].

Infectious human diseases resulting from the consumption of bivalve shellfish are a threat to public health and in many countries represent a significant cost to society $[3,4]$. These health hazards are largely due to the filter-feeding nature of bivalves, as they concentrate and retain bacterial pathogens which are often derived from the contamination of their harvesting areas [4]. These pathogens can then be transmitted to consumers, thus posing a high risk to public health $[3,5]$.

Aeromonas hydrophila is widely distributed in the aquatic environment, being a common contaminant of seafood in diverse geographic areas [6-10]. This bacterium causes a wide spectrum of human infections including gastroenteritis, wound infection, pneumonia, meningitis, endocarditis, and septicaemia (especially in immunocompromised hosts) $[6,11,12]$.

To protect public health and provide safe products to consumers, the European Union Member States have applied the regulations published by the European Commission for the production and marketing of shellfish (RC 853/2004, 2073/2005, and 2285/2015). The ideal procedure to safely obtain bivalves would be their cultivation and harvesting in areas that are not subject to any kind of contamination. However, this is unfeasible from a productive point of view due to the scarcity of such pristine areas [5]. Depuration is a legal requirement in a large number of countries for the marketing of fresh bivalves in order to 
reduce the number of microorganisms to levels legally acceptable for human consumption and, consequently, to protect consumers' health [3,13]. Briefly, depuration is a controlled process in which bivalves are reared in seawater treated with chlorine, ozone, iodine, or UV light for $24-48$ h $[13,14]$. However, bacteria show different sensibilities to the depuration treatment. Some microorganisms are resistant to this process, persisting and multiplying in the shellfish tissue [15-21]. Additionally, the chemical treatments commonly used for seawater disinfection (e.g., chlorine or ozone) may be toxic for aquatic animals, unfavourable to their growth, and affect both the water-filtering activity of bivalve shellfish and the organoleptic quality of bivalves [14,22]. In order to reduce the concentration of potential human pathogens, the development and evaluation of new decontamination strategies with no adverse effects on bivalves is therefore essential. An efficient, environmentally friendly, and scientifically demonstrable solution to control bacterial contaminations in bivalve shellfish is phage therapy. Phages are viruses that only infect bacteria, being abundant in the environment and assuming a relevant role in bacterial population control in natural systems [23]. These viruses are target-specific and self-replicating rapid bactericides that do not affect animal cells [24]. Currently, the potential use of phage therapy in agriculture, veterinary biocontrol, food safety, and in the clinical treatment of human infections is being studied worldwide. Over the last few years, the use of phages on inactivate pathogenic bacteria in bivalves has gained momentum due to their inherent low toxicity [25]. Four studies have already reported the simultaneous use of depuration and phage biocontrol to eliminate pathogenic bacteria in bivalves [19,26-28]. For the first time, Rong et al. (2014) have evaluated the application of phages during the process of depuration on artificially contaminated oysters. Their results demonstrated that the application of phage VPp1 could reduce the population of Vibrio parahaemolyticus (with a maximum decrease of approximately $2.8 \mathrm{log}$ CFU/g) in infected oysters [19]. Jun et al. (2014) have also reported the decrease of $V$. parahaemolyticus (by approximately $5.8 \log \mathrm{CFU} / \mathrm{g}$ at an MOI of 10) after $72 \mathrm{~h}$ of phage pVp-1 application on artificially contaminated oysters in static systems [26]. Pereira and co-workers have revealed the viability of phage application to decrease bacterial population in both artificially and naturally contaminated bivalve shellfish during pilot-scale depuration, simulating the mechanical depuration strategies currently used $[27,28]$. These studies have shown that phage application during depuration procedures improves the microbiological safety of bivalves for human consumption by bolstering decontamination effectiveness, subsequently demonstrating that this technology can be carried out in the bivalve shellfish industry $[27,28]$. Additionally, this methodology cuts the time needed for depuration and, thus, diminishes its related expenses [27,28]. Be that as it may, these studies are limited to three bacterial strains (V. parahaemolyticus, Escherichia coli, and Salmonella enterica serovar Typhimurium), excluding some other important bacteria implicated in human infectious diseases transmitted by bivalve consumption such as Aeromonas, (namely, A. hydrophila) [3,29,30]. Therefore, the aim of this study was to evaluate the efficiency of three new phages (AH-1, AH-4, and AH-5) to control A. hydrophila in order to study their potential application during the depuration process. Several phages infecting $A$. hydrophila, isolated from different environments around the world, have already been characterized [29,31-39] and have been successfully used to treat infections [29,32-34,36,40-43]. The assays were performed in vitro and in vivo using artificially contaminated cockles with $A$. hydrophila.

\section{Results}

\subsection{Phage Isolation and Enrichment}

Phages AH-1, AH-4, and AH-5 formed clear plaques on the host strain with a diameter of $0.5-2 \mathrm{~mm}$ (Figure 1$)$. High titre suspensions $\left[10^{9}\right.$ plaque-forming units $\left.(\mathrm{PFU} / \mathrm{mL})\right]$ were produced for the three phages. 

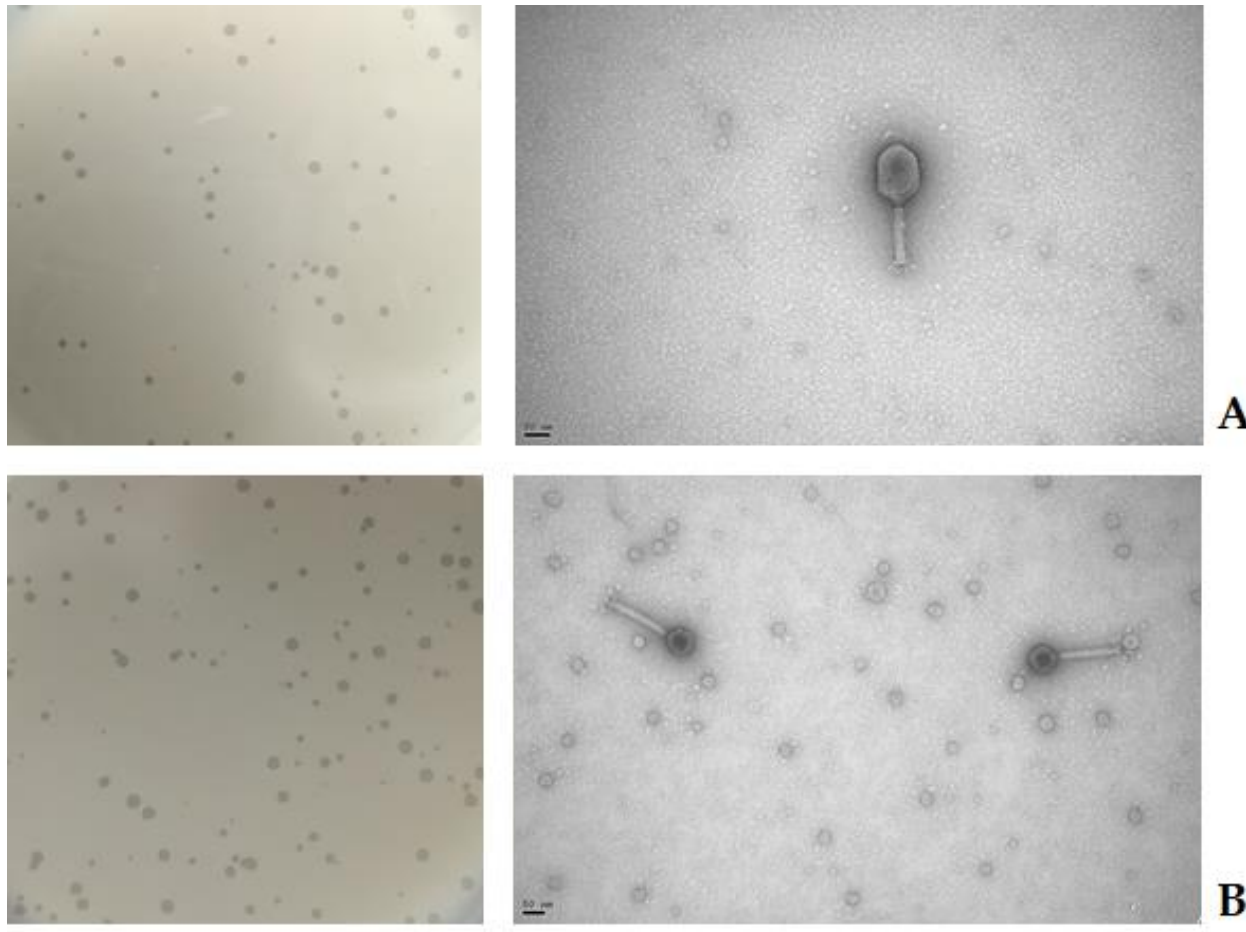

A
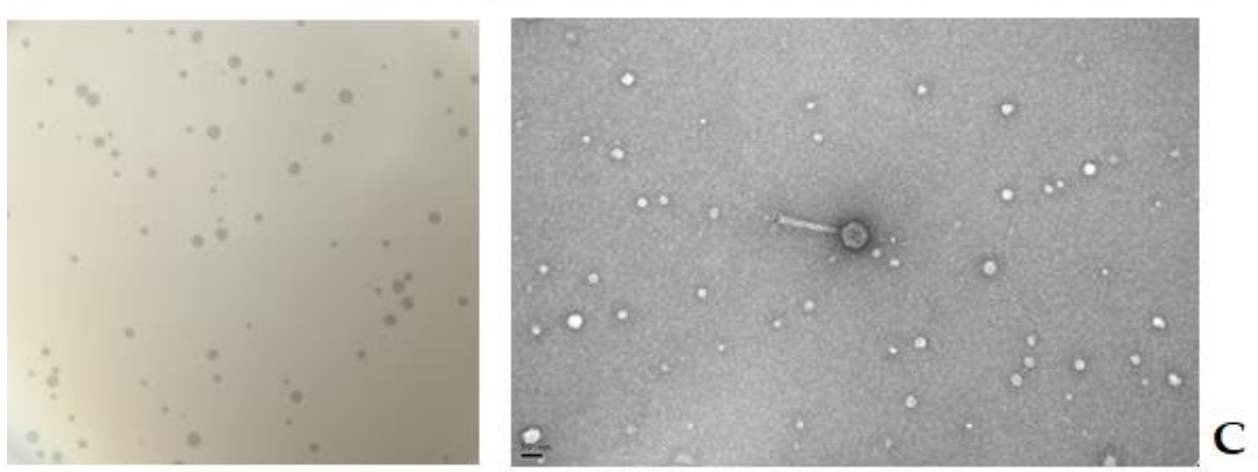

Figure 1. Phage plaque morphologies and electron micrographs of $A$. hydrophila phages: (A) Phage AH-1; (B) Phage AH-4; and (C) Phage AH-5. The bars represent $50 \mathrm{~nm}$.

\subsection{Virion Morphology}

Based on the morphological analysis by TEM (Figure 1), all phages were identified as order Caudovirales and family Myoviridae of double-stranded DNA phages (Figure 1). Phage AH-1 has a rigid and contractile tail and an elongated icosahedral head of $75 \pm 3 \mathrm{~nm}$ width and $104 \pm 4 \mathrm{~nm}$ long. Phages AH-4 and AH-5 have an icosahedral head with $57 \pm 2 \mathrm{~nm}$ width and contractile tail ranging from $130 \pm 10 \mathrm{~nm}$.

\subsection{Phage Host Range Determination and Efficiency of Plating (EOP) Analysis}

Spot tests indicate that phages $\mathrm{AH}-1, \mathrm{AH}-4$, and $\mathrm{AH}-5$, besides their host, could form completely cleared zones on 2, 3, and 1 of the 19 strains tested, respectively (Table 1). The phage AH-1 infected S. typhimurium ATCC 13311 and A. hydrophila 839, presenting an efficiency of 56.10 and $83.33 \%$, respectively (Table 1). Phage AH-4 infected Bioluminescent E. coli, S. typhimurium ATCC 13311, and A. hydrophila 839 with an efficiency of 3.31, 10.17, and $91.14 \%$, respectively (Table 1). Phage AH-5 infected only A. hydrophila 839 with $76.19 \%$ efficacy. 
Table 1. Host range of phages $\mathrm{AH}-1, \mathrm{AH}-4$, and $\mathrm{AH}-5$ determined on 19 bacterial strains. Clear lysis zone, (+); no lysis zone, $(-)$. The plating with the host strain was considered as EOP $=100 \%$.

\begin{tabular}{|c|c|c|c|c|c|c|}
\hline \multirow{2}{*}{ Species } & \multicolumn{3}{|c|}{ Infectivity of Phage } & \multicolumn{3}{|c|}{ Efficacy of Plating (\%) } \\
\hline & AH-1 & AH-4 & AH-5 & AH-1 & AH-4 & AH-5 \\
\hline Aeromonas hydrophila ATCC 7966 & + & + & + & 100 & 100 & 100 \\
\hline Aeromonas hydrophila 839 & + & + & + & $83.3 \pm 3.52$ & $91.14 \pm 5.73$ & $76.19 \pm 2.61$ \\
\hline Aeromonas caviae 838 & - & - & - & 0 & 0 & 0 \\
\hline Aeromonas salmonicida CECT 894 & - & - & - & 0 & 0 & 0 \\
\hline Aeromonas IR13 & - & - & - & 0 & 0 & 0 \\
\hline Bioluminescent Escherichia coli & - & + & - & 0 & $3.31 \pm 0.50$ & 0 \\
\hline Escherichia coli ATCC 25922 & - & - & - & 0 & 0 & 0 \\
\hline Escherichia coli ATCC 13706 & - & - & - & 0 & 0 & 0 \\
\hline Listeria innocua NCTC 11288 & - & - & - & 0 & 0 & 0 \\
\hline Listeria monocytogenes NCTC 1194 & - & - & - & 0 & 0 & 0 \\
\hline Photobacterium damselae damselae DSM 7482 & - & - & - & 0 & 0 & 0 \\
\hline Salmonella typhimurium ATCC 13311 & + & + & - & $56.10 \pm 2.32$ & $10.17 \pm 0.35$ & 0 \\
\hline Salmonella typhimurium ATCC 14028 & - & - & - & 0 & 0 & 0 \\
\hline Salmonella typhimurium WG49 & - & - & - & 0 & 0 & 0 \\
\hline Shigella flexneri DSM 4782 & - & - & - & 0 & 0 & 0 \\
\hline Staphylococcus aureus ATCC 6538 & - & - & - & 0 & 0 & 0 \\
\hline Vibrio parahaemolyticus DSM 27657 & - & - & - & 0 & 0 & 0 \\
\hline Vibrio anguillarum DSM 21597 & - & - & - & 0 & 0 & 0 \\
\hline Aliivibrio fischeri ATCC 49387 & - & - & - & 0 & 0 & 0 \\
\hline
\end{tabular}

\subsection{One-Step Growth Curve Analysis}

Growth curves for phages AH-1, AH-4, and AH- 5 were determined in TSB at $25{ }^{\circ} \mathrm{C}$ (Figure 2). From the triphasic curves obtained, phage AH-1 presented an eclipse time of $60 \mathrm{~min}$, a latent period of $80 \mathrm{~min}$, and a burst size of $39 \pm 5 \mathrm{PFU} /$ host cell. Phage AH-4 is characterized by an eclipse time of $50 \mathrm{~min}$, a latent period of 70, and a burst size of $51 \pm 9$ PFU/host cell. Phage AH-5 is characterized by an eclipse period of $40 \mathrm{~min}$, a latent period of $70 \mathrm{~min}$, and a burst size of $112 \pm 5 \mathrm{PFU} /$ host cell.

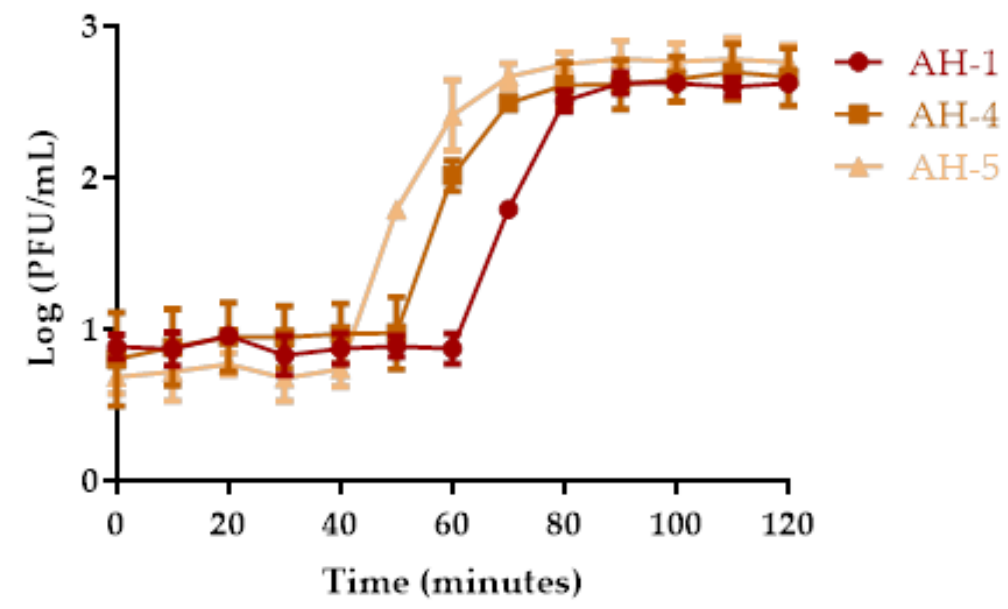

Figure 2. One-step growth curves of phages AH-1, AH-4, and AH-5 in the presence of A. hydrophila as the host. Values represent the mean of three independent experiments, and error bars represent the standard deviation. 


\subsection{Bacterial Killing Curves}

\subsubsection{Bacterial Killing Curves Using Single Phage Suspensions}

Bacterial density in the BC increased $3.8 \log \mathrm{CFU} / \mathrm{mL}$ (ANOVA, $p<0.05$, Figure $3 \mathrm{~A}$ ) during the $12 \mathrm{~h}$ of incubation. The maximum bacterial decrease with phages $\mathrm{AH}-1, \mathrm{AH}-4$, and AH-5 was, respectively, 7.7, 4.9, and $4.5 \log \mathrm{CFU} / \mathrm{mL}$ (ANOVA, $p<0.05$, Figure $3 \mathrm{~A}$ ), achieved after 8-10 $\mathrm{h}$ incubation when compared with those of the bacterial control (BC). However, after $6 \mathrm{~h}$ of incubation the inactivation rate was already 6.1, 4.8, and $4.3 \mathrm{log}$ $\mathrm{CFU} / \mathrm{mL}$ (ANOVA, $p<0.05$, Figure $3 \mathrm{~A}$ ) for phages AH-1, AH-4, and AH-5, respectively. After $12 \mathrm{~h}$ of treatment, the rate of inactivation was still considerably high (ANOVA, $p<0.05$, Figure 3A) for all phages $(6.0,3.5$, and $2.4 \log \mathrm{CFU} / \mathrm{mL}$ for phages $\mathrm{AH}-1, \mathrm{AH}-4$, and $\mathrm{AH}-5$, respectively). The rate of bacterial inactivation with the phage $\mathrm{AH}-1$ was, in general, significantly higher (ANOVA, $p<0.05$, Figure $3 \mathrm{~A}$ ) than those obtained with phages $\mathrm{AH}-4$ and AH-5. During the $12 \mathrm{~h}$ of incubation, the rate of bacterial inactivation with phages AH-4 and AH-5 was similar (ANOVA, $p>0.05$ ).
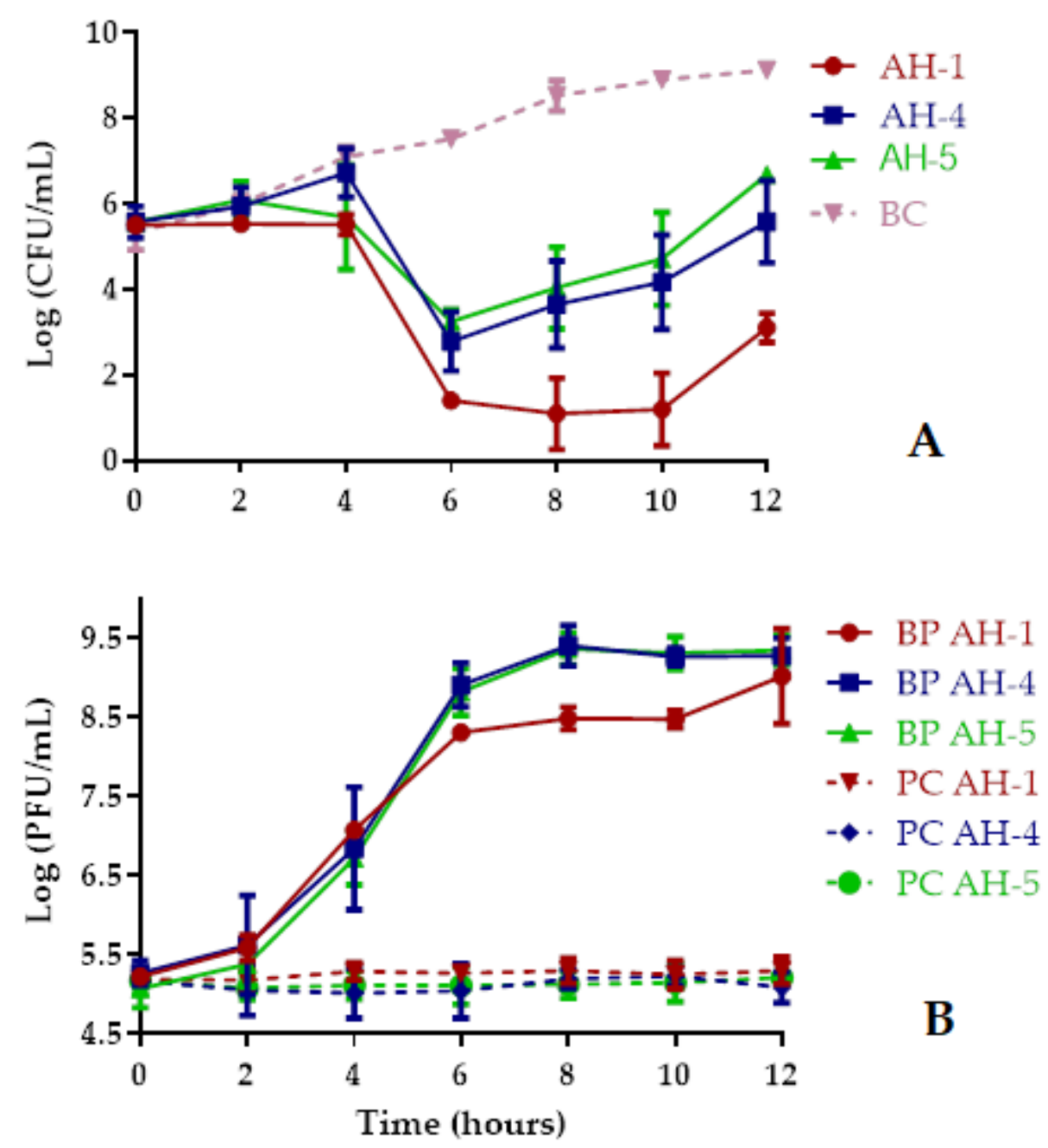

Figure 3. Inactivation of $A$. hydrophila by the three phages (AH-1, $\mathrm{AH}-4$, and $\mathrm{AH}-5)$ during $12 \mathrm{~h}$ using an MOI of 1. (A) Bacterial concentration: $\mathrm{BC}$, bacteria control; $\mathrm{BP}$, bacteria plus phage. (B) Phage concentration: PC, phage control; BP, bacteria plus phage. Values represent the mean of the three experiments and error bars represent the standard deviation.

No decrease in the phage survival was observed during the $12 \mathrm{~h}$ of the experiments for the phages alone, nor in the presence of the host (Figure 3B) in the different experiments. While the phage control $(\mathrm{PC})$ remained constant throughout the experiment (ANOVA, $p>0.05)$, when phages $\mathrm{AH}-1, \mathrm{AH}-4$, and $\mathrm{AH}-5$ were incubated in the presence of the host, 
a significant increase of 3.8, 4.0, and $4.3 \log$ PFU/mL, respectively, was observed (ANOVA, $p<0.05$, Figure 3B).

\subsubsection{Bacterial Killing Curves Using Phage Cocktails}

Bacterial density in the BC increased $3.2 \log \mathrm{CFU} / \mathrm{mL}$ (ANOVA, $p<0.05$, Figure $4 \mathrm{~A}$ ) during the $12 \mathrm{~h}$ of incubation. In general, the rates of inactivation were statistically similar (ANOVA, $p>0.05$ ) for the four phage cocktails during the $12 \mathrm{~h}$ of incubation (Figure $4 \mathrm{~A}$ ).
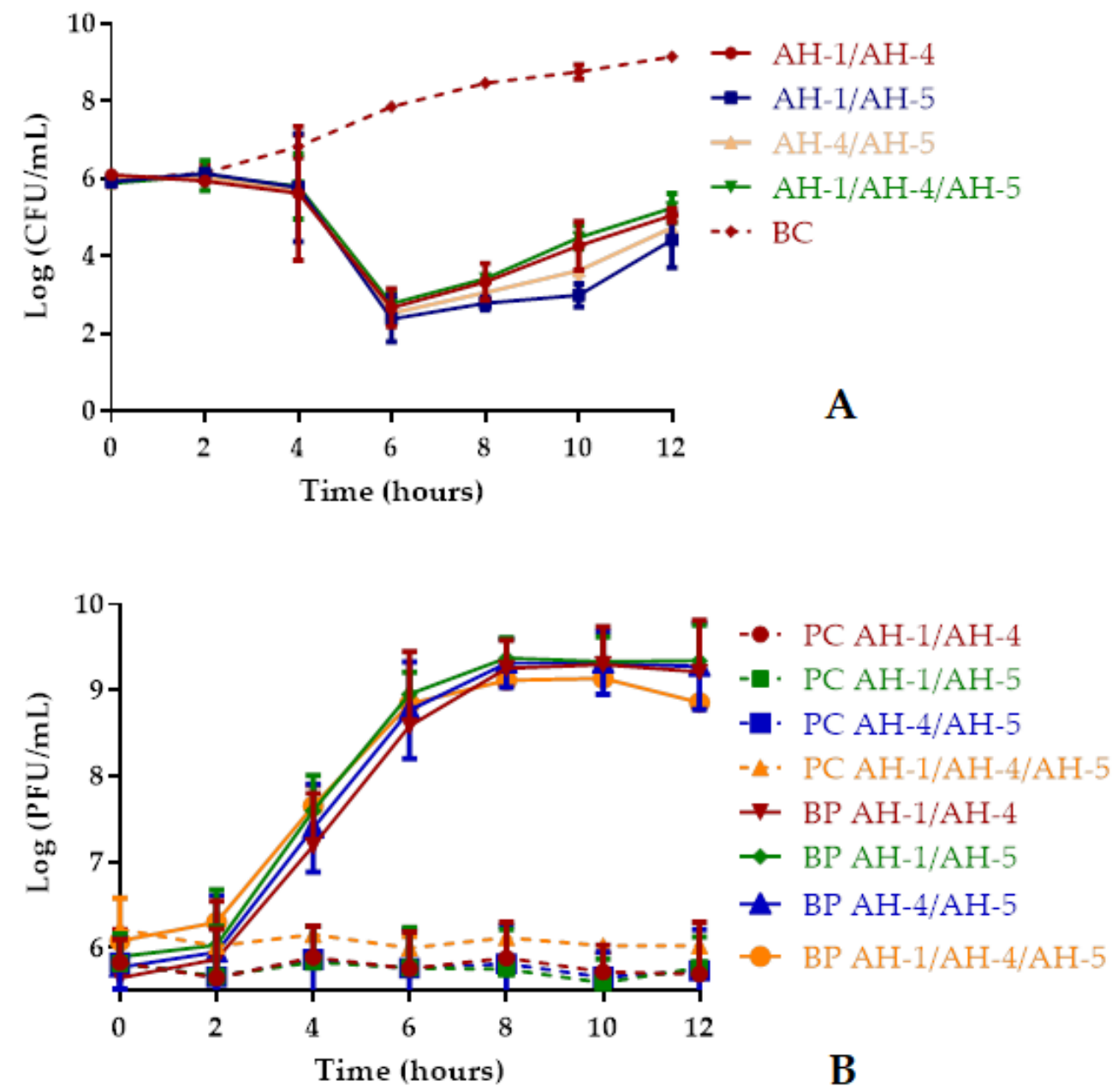

Figure 4. Inactivation of $A$. hydrophila by phage cocktails (AH-1/AH-4, AH-1/AH-5, AH-4/AH-5, and $\mathrm{AH}-1 / \mathrm{AH}-4 / \mathrm{AH}-5$ ) at an MOI of 1 during $12 \mathrm{~h}$. (A) Bacterial concentration: BC, bacteria control; $\mathrm{BP}$, bacteria plus phage. (B) Phage concentration: PC, phage control; BP, bacteria plus phage. AH-1, phage AH-1; AH-4, phage AH-4; and AH-5, phage AH-5. Values represent the mean of the three experiments, and the error bars represent the standard deviation.

The maximum inactivation of $A$. hydrophila with the phage cocktails $\mathrm{AH}-1 / \mathrm{AH}-4$, $\mathrm{AH}-1 / \mathrm{AH} 5, \mathrm{AH}-4 / \mathrm{AH}-5$, and $\mathrm{AH}-1 / \mathrm{AH}-4 / \mathrm{AH}-5$ was 5.2, 5.8, 5.4, and $5.1 \log \mathrm{CFU} / \mathrm{mL}$ achieved after $6,10,8$, and $6 \mathrm{~h}$ of incubation, respectively, when compared with those of the bacterial control (BC) (Figure 4A). However, after $6 \mathrm{~h}$ the rate of inactivation was already considerably high (ANOVA, $p<0.05$, Figure $4 \mathrm{~A}$ ) with the phage cocktails AH-1/AH-5, $\mathrm{AH}-4 / \mathrm{AH}-5$, and $\mathrm{AH}-1 / \mathrm{AH}-4 / \mathrm{AH}-5$ (5.5, 5.3, and $5.1 \log \mathrm{CFU} / \mathrm{mL}$, respectively). After $12 \mathrm{~h}$ of incubation, the rate of inactivation was still considerably high (4.1, 4.7,4.4, and $3.9 \mathrm{log}$ $\mathrm{CFU} / \mathrm{mL}$ for the phage cocktails AH-1/AH-4, AH-1/AH5, AH-4/AH-5, and AH-1/AH-4/ AH-5, respectively, ANOVA, $p<0.05$ ) (Figure $4 \mathrm{~A}$ ). The phage controls (PC) remained constant during the $12 \mathrm{~h}$ of the assay (ANOVA, $p>0.05$, Figure $4 \mathrm{~B}$ ). In the case of the phage cocktails incubated in the presence of A. hydrophila, a significant increase (ANOVA, $p<0.05$, 
Figure 4B) of 3.6, 3.5, 3.5, and 2.8 log PFU/mL was observed for AH-1/AH-4, AH-1/AH5, $\mathrm{AH}-4 / \mathrm{AH}-5$, and $\mathrm{AH}-1 / \mathrm{AH}-4 / \mathrm{AH}-5$, respectively, after $8 \mathrm{~h}$ of incubation.

\subsection{Determination of the Rate of Emergence of Phage-Resistant Mutants}

A. hydrophila showed different rates of phage-resistant mutants for single phage suspensions and phage cocktails (Table 2). The frequency of $A$. hydrophila mutants resistant to phage AH-1 $\left(3.10 \times 10^{-3}\right)$ and AH-4 $\left(1.14 \times 10^{-3}\right)$ was higher than the observed with phage AH-5 $\left(5.02 \times 10^{-4}\right)$ and the phage cocktails $\left(8.26 \times 10^{-4}, 6.40 \times 10^{-4}, 7.13 \times 10^{-4}\right.$, and $5.99 \times 10^{-4}$ for the phage cocktails AH-1/AH-4, AH-1/AH-5, AH-4/AH-5, and AH-1/AH-4/AH-5, respectively).

Table 2. Frequency of emergence of $A$. hydrophila spontaneous phage-resistant.

\begin{tabular}{cccc}
\hline $\begin{array}{c}\text { Phages/Phage } \\
\text { Cocktails }\end{array}$ & $\begin{array}{c}\text { Control Sample } \\
\text { (CFU/mL) }\end{array}$ & $\begin{array}{c}\text { Sample Treated with } \\
\text { Phages }\end{array}$ & $\begin{array}{c}\text { Frequency of } \\
\text { Mutants }\end{array}$ \\
\hline AH-1 & $1.24 \pm 0.45 \times 10^{9}$ & $3.85 \pm 2.77 \times 10^{4}$ & $3.10 \times 10^{-3}$ \\
\hline AH-4 & $2.41 \pm 0.93 \times 10^{9}$ & $2.75 \pm 1.20 \times 10^{4}$ & $1.14 \times 10^{-3}$ \\
\hline AH-5 & $3.27 \pm 0.11 \times 10^{9}$ & $1.64 \pm 0.35 \times 10^{4}$ & $5.02 \times 10^{-4}$ \\
\hline $\mathrm{AH}-1 / \mathrm{AH}-4$ & $6.43 \pm 0.12 \times 10^{9}$ & $5.32 \pm 2.46 \times 10^{4}$ & $8.26 \times 10^{-4}$ \\
\hline $\mathrm{AH}-1 / \mathrm{AH}-5$ & $8.15 \pm 0.36 \times 10^{9}$ & $5.22 \pm 3.12 \times 10^{4}$ & $6.40 \times 10^{-4}$ \\
\hline $\mathrm{AH}-4 / \mathrm{AH}-5$ & $2.17 \pm 0.58 \times 10^{9}$ & $1.55 \pm 1.15 \times 10^{4}$ & $7.13 \times 10^{-4}$ \\
\hline $\mathrm{AH}-1 / \mathrm{AH}-4 / \mathrm{AH}-5$ & $9.23 \pm 2.08 \times 10^{9}$ & $5.53 \pm 3.24 \times 10^{4}$ & $5.99 \times 10^{-4}$ \\
\hline
\end{tabular}

\subsection{Growth Curve of Phage-Resistant A. hydrophila Strains}

The resistant mutants (PR1-PR10) retained resistance to AH-1 infection through 10 consecutive subcultures, and no morphological changes were observed in their colonies. The resistant mutants PR-8, PR-9, and PR-10 exhibited growth impairment after $12 \mathrm{~h}$ of incubation with the latter being the most affected, reaching less than $57 \%$ of the O.D.600 $\mathrm{nm}$ obtained by the parental strain (BC). However, after $24 \mathrm{~h}$ of incubation the growth of the resistant mutants (PR1-PR10) was similar to that obtained by the parental strain (BC) (Figure 5, ANOVA, $p>0.05$ ). Phages AH-4 and AH-5 did not infect the phage AH-1resistant mutants (PR1-PR10).

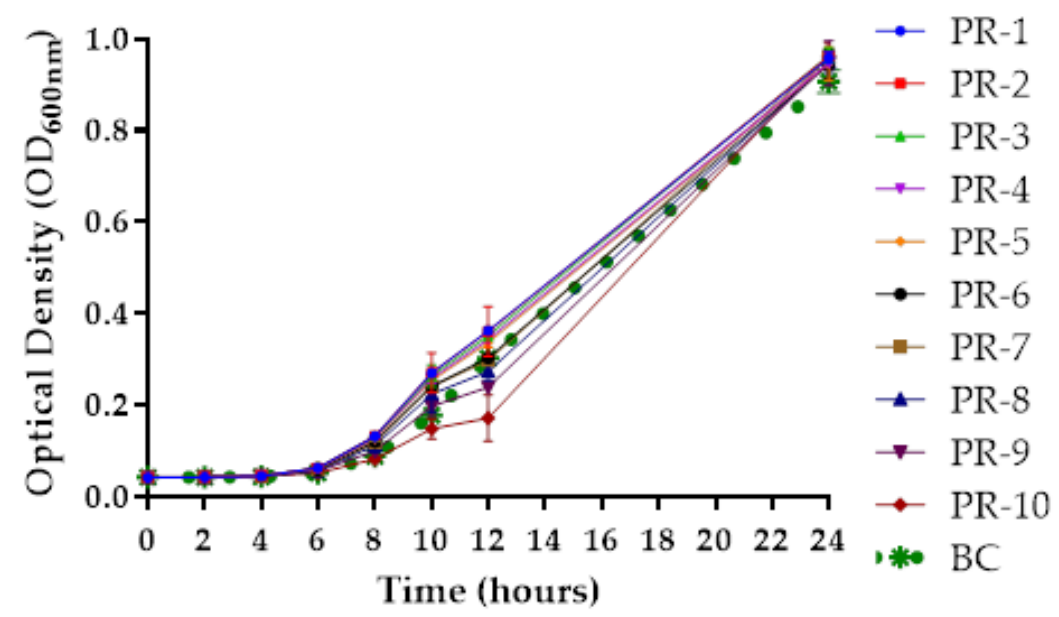

Figure 5. Growth curve of phage-resistant A. hydrophila strains during $24 \mathrm{~h}$, with optical density (OD) readings at $600 \mathrm{~nm}$. PR-1-PR10, phage resistant bacteria strains; BC, bacteria sensitive to phage $\mathrm{AH}-1$. Values represent the mean of three three independent experiments and error bars represent the standard deviation. 


\subsection{Bacterial Killing Curves at Different MOIs}

At MOIs of 1,10,100, and 1000, the maximum A. hydrophila inactivation with phage $\mathrm{AH}-1$ was, respectively, $7.5 \log \mathrm{CFU} / \mathrm{mL}$ after $10 \mathrm{~h}$ of incubation, and 6.5, 6.7, and $6.4 \log \mathrm{CFU} / \mathrm{mL}$, after $8 \mathrm{~h}$ of incubation when compared with those of the bacterial control. However, after $2 \mathrm{~h}$ the rate of inactivation was still considerably high (2.8 and $3.0 \log$ CFU / mL; ANOVA, $p<0.05$ ) for the MOI of 100 and 1000, respectively (Figure 6A). During the first $4 \mathrm{~h}$ of incubation, the increase in MOI significantly increased the inactivation factor (ANOVA, $p<0.05$ ). However, after $4 \mathrm{~h}$ of incubation, there were no significant differences within the different MOIs (ANOVA, $p>0.05$ ). After 6 and $8 \mathrm{~h}$, the rate of inactivation was similar for all tested MOIs (Figure $6 \mathrm{~A}$ ). At the end of the experiment, the rate of bacterial inactivation with the MOI of 1 and 100 (reduction of 6.0 and $6.7 \log \mathrm{CFU} / \mathrm{mL}$, respectively) was significantly higher (ANOVA, $p<0.05$ ) than the one obtained with the MOI of 10 and 1000 (5.8 and $4.7 \log \mathrm{CFU} / \mathrm{mL}$, respectively).
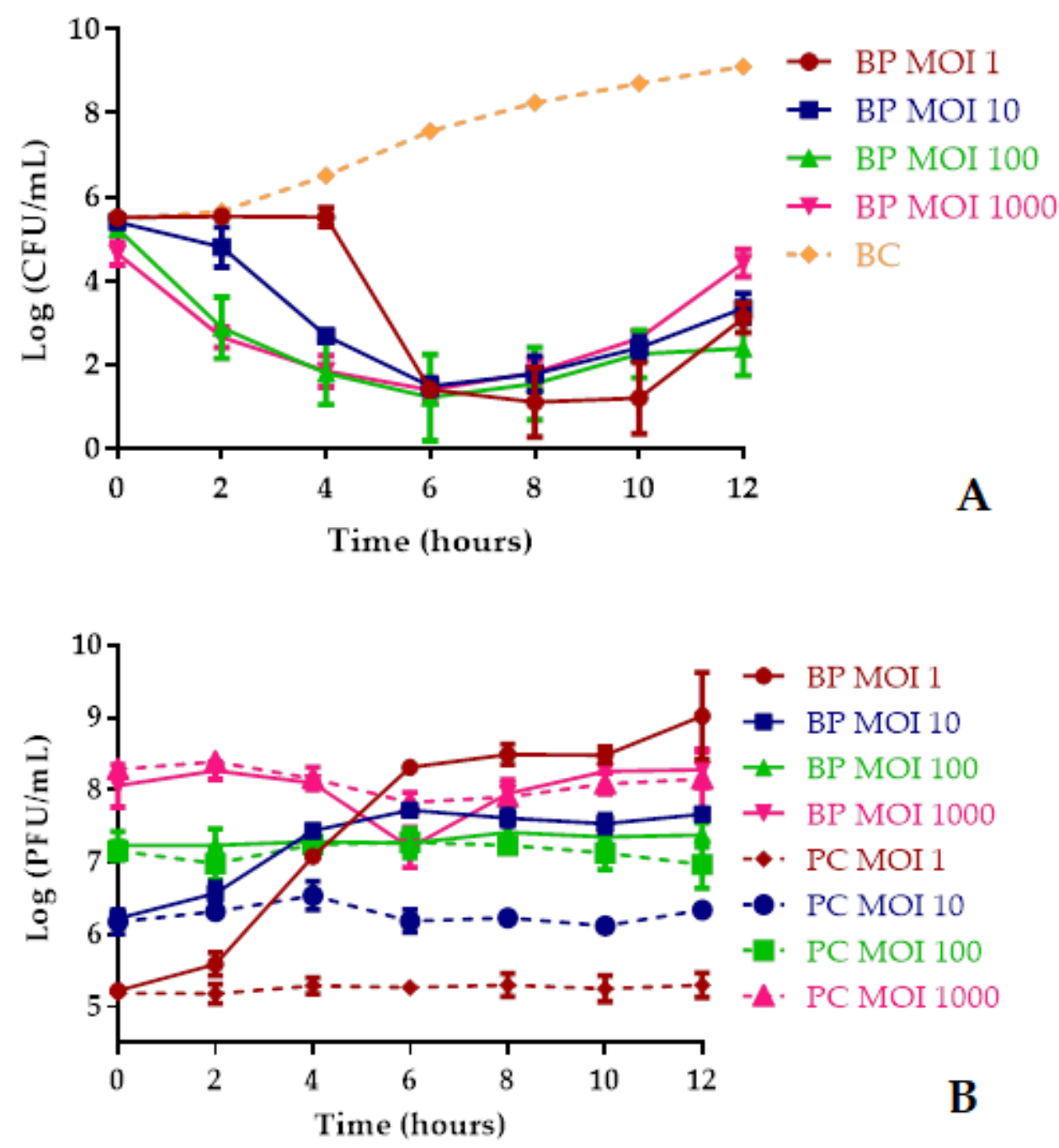

Figure 6. Inactivation of $A$. hydrophila by phage AH-1 at MOIs of 1, 10, 100, and 1000 during $12 \mathrm{~h}$. (A) Bacterial concentration: $\mathrm{BC}$, bacteria control; BP, bacteria plus phage. (B) Phage concentration: PC, phage control; BP, bacteria plus phage. Values represent the mean of the three independent experiments and error bars represent the standard deviation.

The bacterial density in the $\mathrm{BC}$ increased $3.8 \log \mathrm{CFU} / \mathrm{mL}$ (ANOVA, $p<0.05$ ) during the $12 \mathrm{~h}$ of incubation (Figure 6A). The phage concentration in the controls (PC) remained constant during the $12 \mathrm{~h}$ timeframe of the experiments (ANOVA, $p>0.05$, Figure 6B) and when phage AH-1 was incubated in the presence of its host, a significant increase 
(ANOVA, $p<0.05$ ) in the phage particle concentration $(3.8$ and $1.5 \log$ PFU $/ \mathrm{mL}$ after 12 and $6 \mathrm{~h}$ of incubation) was observed for the MOI of 1 and 10, respectively (Figure 6B). No significant difference was observed when phage AH-1 was incubated in the presence of the A. hydrophila (BP) at an MOI of 100 and 1000 when compared with the phage control (ANOVA, $p>0.05$, Figure $6 \mathrm{~B}$ ).

\subsection{Phage Application during Cerastoderma edule Depuration in a Static System}

The total concentration of cultivatable bacteria present in the cockles at the start of the assay was $2.7 \log \mathrm{CFU} / \mathrm{g}$ (Figure 7A) and no Aeromonas species were detected. The bacterial density in the bacterial control in the cockles at the start of the assay was $4.4 \log \mathrm{CFU} / \mathrm{g}$. The bacterial density in the bacterial control (BC) and animal control (CC) remained constant (ANOVA, $p>0.05$, Figure $7 \mathrm{~A}$ ) during the $12 \mathrm{~h}$ of treatment.
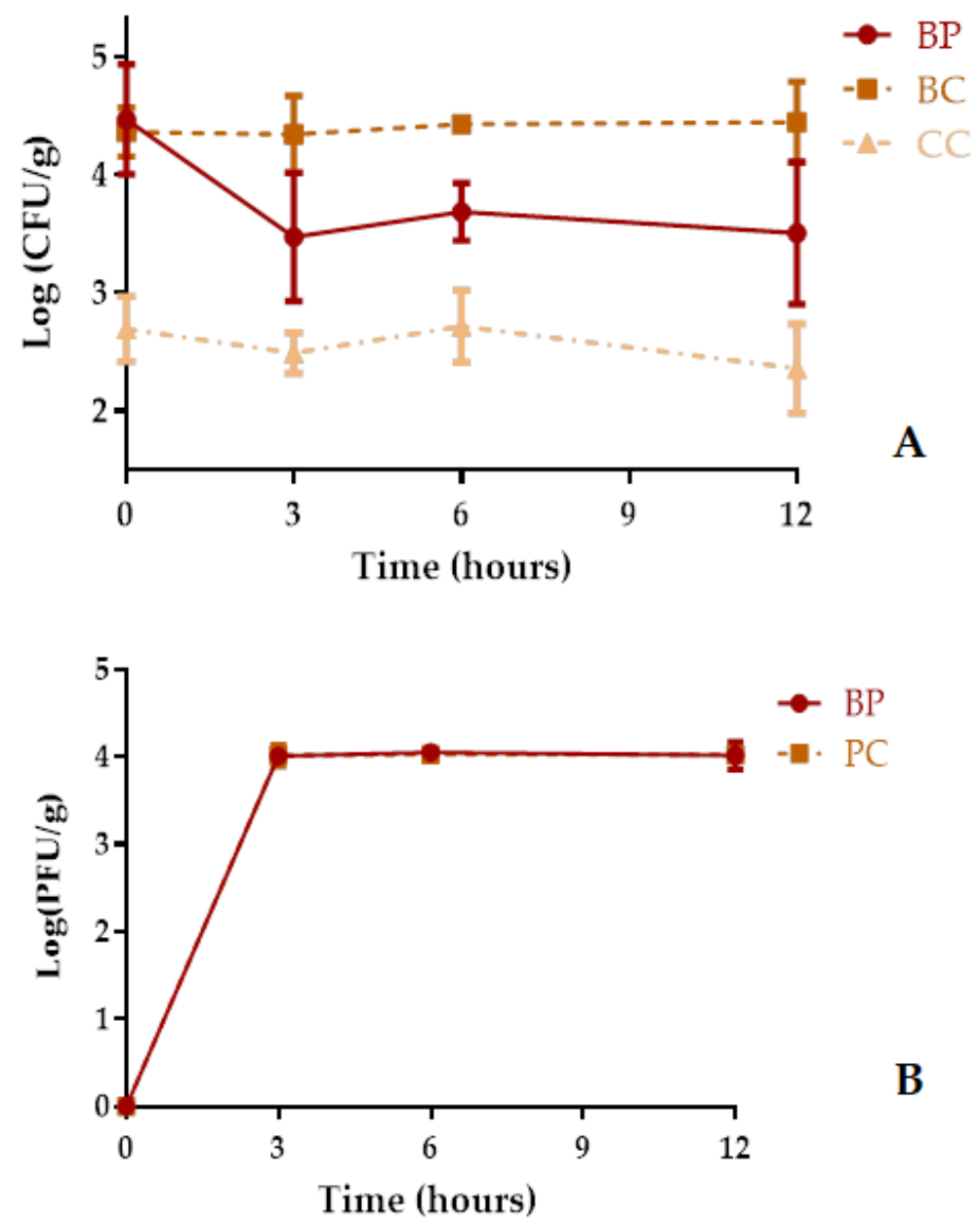

Figure 7. Inactivation of $A$. hydrophila in artificially contaminated cockles using phage AH-1 at a MOI of 1 during 12 h. (A) Bacterial concentration: CC, uninfected group (control cockles); BC, bacteria control; BP, bacteria plus phage. (B) Phage concentration: PC, phage control; BP, bacteria plus phage. Values represent the mean of the three experiments and error bars represent the standard deviation.

The maximum rate of cultivable bacteria inactivation in cockles treated with phage AH-1, relatively to the bacterial control, was $1.0 \log$ CFU/g (ANOVA, $p<0.05$, Figure 7A) achieved after $12 \mathrm{~h}$ of treatment. However, after $3 \mathrm{~h}$, the rate of inactivation was already considerably high $(0.9 \log \mathrm{CFU} / \mathrm{mL}$; ANOVA, $p<0.05)$.

The abundance of phage AH-1 in cockles in the absence (PC) and presence of the host A. hydrophila (BP, Figure 7B) increased during the first $3 \mathrm{~h}$ and then remained constant until the end of the treatment. 


\section{Discussion}

The elimination of $A$. hydrophila in bivalve molluscs is very important for public health. However, the treatments currently available for bivalves' decontamination are not fully efficient nor environmentally safe. While some studies have demonstrated that phages can be used to successfully control pathogenic bacteria associated with shellfish consumption $[19,26,28,44,45]$, no effort has been made to evaluate their effectiveness to control A. hydrophila in bivalves molluscs. In this study, the results showed that the application of phages could reduce the population of A. hydrophila.

Phage specificity is very important in phage therapy, and it was observed for the phage AH-5 tested in this study. However, phages AH-1 and AH-4, besides their host A. hydrophila ATCC 7966, can also infect other A. hydrophila strains and other bacterial species frequently associated with infectious outbreaks through bivalve shellfish consumption. Phage AH-1 infected A. hydrophila 839 and S. typhimurium ATCC 13311, and phage AH-4 infect A. hydrophila 839, an E. coli strain (bioluminescent E. coli) and a Salmonella strain (S. typhimurium ATCC 13311) which belong to different bacterial genera. Similar results were already observed in other studies [44-46]. These results suggest that phages AH-1 and AH-4 can be used not only to control A. hydrophila but also other human pathogenic bacteria associated with shellfish consumption, namely E. coli and S. typhimurium. According to Mirzaei and Nilsson (2015), a collection of phages with wide host ranges would facilitate the creation of phage libraries and reduce study costs [47]. The effectiveness of phages AH- 1 and AH- 4 was also tested against other Aeromonas species and other bacterial genera, but none of these bacteria was infected by the two phages (Table 1). The majority of marine phages are highly host-specific [48-50] and $73 \%$ of them lyse only the original host bacterium [50], as the phage AH-5. El-araby et al. (2016) demonstrated that two A. hydrophila phages infected only one A. salmonicida of the tested six strains and did not infect any isolates of non-Aeromonas bacteria tested [36]. In another study, Akmal et al. (2020) observed that the phage Akh-2 lysed only four A. hydrophila strains (four of the seven strains tested) and could not infect the other 23 strains tested [29]. In the future, new phages need to be isolated and tested together with phages $\mathrm{AH}-1, \mathrm{AH}-4$, and $\mathrm{AH}-5$ to produce a cocktail with a broader spectrum of activity against $A$. hydrophila and even to control other pathogenic bacteria associated with shellfish consumption.

Some studies have demonstrated that phages with high burst sizes and short lytic cycles increase the efficiency of phage therapy $[44,51,52]$. However, high burst sizes are usually followed by a more extensive latency period [53]. Nevertheless, the true correlation between these properties and therapy success is not yet fully understood [54,55]. Although the burst size was higher for phage AH-5 (112 \pm 5 PFU/host cell) than for phages AH-1 (39 \pm 5 PFU/host cell) and AH-4 (51 \pm 9 PFU/host cell) (Figure 2), the in vitro phage inactivation was higher with phage $\mathrm{AH}-1$ (maximum inactivation of 7.7, 4.9 and $4.5 \log \mathrm{CFU} / \mathrm{mL}$ for phages AH-1, AH-4, and AH-5, respectively, Figure $3 \mathrm{~A}$ ), suggesting that other factors regulate the phage-bacteria interaction.

A. hydrophila was effectively inactivated by the three phages $\mathrm{AH}-1, \mathrm{AH}-4$, and $\mathrm{AH}-5$ (Figure $3 \mathrm{~A}$ ), but the phage AH-1 was the most effective (with a maximum of inactivation of 7.7 against 4.9 and $4.5 \log \mathrm{CFU} / \mathrm{mL}$ for $\mathrm{AH}-4$ and $\mathrm{AH}-5$ after $8-10 \mathrm{~h}$ of incubation; most of the inactivated bacteria did not regrow after treatment, i.e., when phage AH-1 was used). All phage cocktails tested (two or all three phages mixed) to inactivate A. hydrophila were more efficient to control the bacterial growth than phages AH-4 and AH-5 alone. These results are in accordance with other studies $[28,51,56]$ that achieved a higher bacterial decrease by using phage cocktails, than that obtained with single phage suspensions. However, phage AH- 1 (with a maximum reduction of $7.7 \log \mathrm{CFU} / \mathrm{mL}$ (Figure 4A)) was more efficient than the other phages alone (with maximum reduction of 4.5-4.9 $\log \mathrm{CFU} / \mathrm{mL}$ (Figure $4 \mathrm{~A}$ )) and phage cocktails (with a maximum reduction of 5.1-5.8 $\log$ CFU / mL (Figure 4A)). When the most efficient phage (AH-1) was used in the cocktails, the efficiency of the phage cocktails was not better than with phage AH-1 alone. This can be explained by the fact that phage AH-1 may target the same bacterial receptor 
as phages $\mathrm{AH}-4$ and $\mathrm{AH}-5$, expaining why phages $\mathrm{AH}-4$ and $\mathrm{AH}-5$ did not infect phage AH-1-resistant mutants (PR1-PR10). As phage cocktails, besides being used to increase bacterial inactivation and to increase the host range, are also used to delay the development of phage-resistant mutants, the type of bacterial receptor that each phage uses to infect its host should be considered when selecting the phages to be included in a specific cocktail. Filippov et al. (2011) showed that the use of phage cocktails can overcome the problem of bacterial resistance, but that is only the case if the phages exploit different receptors. Further studies, including the identification of the bacterial receptors used by the tested phages to infect $A$. hydrophila, are necessary to confirm this hypothesis [57].

When phage AH-1 was used, in general, the bacterial regrowth was lower than that observed when the other phages were tested alone or in phage cocktails. However, the use of phage AH-1, as well as the use of other single-phage suspensions and phage cocktails, did not prevent the occurrence of phage-resistant mutants (Table 2). Nonetheless, the frequency of phage-resistant mutations was low $\left(10^{-3}-10^{-4} \mathrm{CFU} / \mathrm{mL}\right)$ and was slightly lower for the phage cocktails than for the single phage suspensions (Table 2), as was observed in other studies $[56,58,59]$. With such a small mutation frequency, phage resistance should not hinder the use of phages as biocontrol agents against pathogenic bacteria, as has been stated before by other authors $[60,61]$. The diversity between different phage-resistant mutants can be studied through their growth curves. In this study, the resistant mutants PR-8, PR-9, and PR-10 exhibited alterations in their growth. These results are in agreement with several other reports that also showed alterations in the growth of the phage-resistant mutants (namely, a reduction in the growth rate) [62-64].

As the increase in the MOI from 1 to 1000 for phage AH- 1 did not significantly increase the efficiency of treatment, the next experiments were performed with a MOI of 1 . Although bacterial reduction with phage AH-1 occurs sooner at MOIs of 100 and 1000 (with a decrease of 2.8 and $3.0 \log \mathrm{CFU} / \mathrm{mL}$ after $2 \mathrm{~h}$ of incubation (Figure 6A)), the initial doses of the phage AH-1 was not essential due to the phage self-perpetuating nature, revealed by a high increase of phage titers along with bacteria at MOI 1 . The number of phage particles during the $12 \mathrm{~h}$ of incubation in the presence of the host at a MOI of 1 increased more (by $3.8 \log \mathrm{PFU} / \mathrm{mL}$ ) than at an MOI of 1000 (i.e., phage concentration remained similar to that of phage control) (Figure 6B). A high MOI may sometimes be a disadvantage for the success of phage treatment since the bacteria may be inactivated before replicating the phages. This can occur when an overload of phages simultaneously infects a bacterium, leading to lysis due to the presence of high concentrations of lysins, a phenomenon known as "lysis from without" $[53,65,66]$. The regrowth of the bacterial population which takes place after almost $6-10 \mathrm{~h}$, even though it is very slow, could be considered as a constraint to phage therapy application. The increase in the MOI from 1 to 10,100 , or 1000 slightly increased the emergence of phage-resistant mutants, especially after $8 \mathrm{~h}$ of treatment. Similar results have already been observed in other studies $[33,40,67,68]$. Le et al. (2018), observed that the higher the MOI value, the sooner phage-resistant bacterial cells appeared [40]. A similar result was noted by Kim et al. (2012) for the phage PAS 1 against an A. salmonicida, indicating that bacterial resistance appeared after 3, 6, and $24 \mathrm{~h}$ at MOIs 10, 1 , and 0.1 , respectively [68].

One of the current challenges faced when performing phage biocontrol studies is to demonstrate its feasibility in vivo $[27,28,69,70]$. Hence, the efficiency of phage AH-1 was tested using artificially contaminated bivalves. The results of the in vivo experiments showed that phage AH-1 inactivated A. hydrophila, but that the efficacy was lower than that observed in vitro (with a maximum inactivation of $1.0 \log \mathrm{CFU} / \mathrm{g}$ and $7.7 \log \mathrm{CFU} / \mathrm{mL}$, respectively) when compared to the non-treated samples. Similar results have been reported in other studies $[27,28]$. Pereira and colleagues observed that the efficiency of the single suspensions of phages phT4A and ECA2 and the phage cocktail (phT4/ECA2) used to treat cockles artificially contaminated with $E$. coli (with maximum inactivation of $2.0 \mathrm{log}$ $\mathrm{CFU} / \mathrm{g}$ ) was lower than that obtained in in vitro assays (with maximum inactivation of 5.8, 4.7 and $6.2 \log \mathrm{CFU} / \mathrm{mL}$, respectively) [28,59]. In another study, the S. typhimurium 
inactivation rate in vitro using the phage cocktail phSE-2/phSE-5 (with maximum reduction of $2.0 \log \mathrm{CFU} / \mathrm{mL}$ ) was higher than the results recorded in vivo (with maximum reduction of $0.7 \log \mathrm{CFU} / \mathrm{g}$ ) [27,44]. However, the natural bacterial concentration at the beginning of the experiments was considerably high $(2.7 \log \mathrm{CFU} / \mathrm{mL})$ when compared with similar studies $(0.8-1.7 \log \mathrm{CFU} / \mathrm{mL})[27,44]$. This high concentration of natural bacterial species may have hindered the inactivation success if those species are not within the bacteriophage's infection range. Only around $1.7 \log \mathrm{CFU} / \mathrm{mL}$ of the initial bacteria present in the bivalves at the beginning of the experiments $(4.5 \log \mathrm{CFU} / \mathrm{mL})$ were added to the bivalves, corresponding to $A$. hydrophila. Therefore, more than $44 \%$ of the added A. hydrophila cells were inactivated. Bivalves display an uneven and large (internal) surface area, which physically limits the distribution of phage particles and prevents them from reaching their bacterial targets, therby impairing phage replication. On the other hand, the bivalve immune system can remove some of the added phages, hindering the bacterial inactivation. The concentration of phage particles produced in the presence of $A$. hydrophila in the in vitro experiments (an increase of $3.8 \log \mathrm{PFU} / \mathrm{mL}$ ) was higher than that observed in the in vivo experiments (phage concentration in the presence of hosts remains constant).

The reduction of $A$. hydrophila concentration by phage AH-1 in both in vitro and in vivo experiments is an important step forward in the development of an efficient and ecofriendly complement to depuration. However, in order to transfer this technology to industry, more studies are needed using naturally contaminated bivalves, first on a laboratory scale and, afterwards, scaling up to industrial conditions. Further evaluation trials must still be performed (e.g., whole-genome sequencing) in order to identify the presence of genes encoding toxins and/ or antibiotic resistance.

\section{Materials and Methods}

The selection of appropriate phages to be used in phage therapy represents a critical step towards achieving the successful phage-mediated control of pathogenic bacteria. Phages were characterized for their morphology, host-range, efficiency of plating, growth parameters (latent period and burst size), and frequency of emergence of phage resistant mutants. To evaluate the potential of three new phages to control A. hydrophila, and to select the best phage-inactivation conditions to be used in the bivalves decontamination, in vitro assays were performed. The first in vitro experiments were performed in Tryptic Soy Broth medium (TSB; Liofilchem, Roseto degli Abruzz, Italy) using phages individually or combined in cocktails (two or all the three phages mixed together) at a MOI of 1 . As the major concern related to the use of phages to control infections is the emergency of phageresistant mutants, the frequency of emergence of phage resistant mutants was determined using single phage suspensions and phage cocktails. Before application of phages to inactivate $A$. hydrophila during bivalves depuration, it is important to characterize in vitro the dynamics of phage-host replication. The kinetic theory of phage therapy predicts that the MOI could be critical to bacterial inactivation efficiency. For this reason, in a second step, bacterial inactivation was determined using the best phage selected in experiments above at MOIs of 1,10,100, and 1000. Then, the best in vitro phage treatment conditions were used in the in vivo assays using artificially contaminated bivalves with $A$. hydrophila.

\subsection{Bacterial Strains and Growth Conditions}

The bacterial strains used in this study are listed in Table 1. The bacterial strain A. hydrophila (ATCC 7966) was used in this study as a phage host. Staphylococcus aureus (ATCC 6538), S. typhimurium (ATCC 13311 and ATCC 14028), E. coli (ATCC25922 and 13706), V. parahaemolyticus (DSM 27657), V. anguillarum (DSM 21597), A. fischeri ATCC 49387, P. damselae damselae (DSM 7482), S. flexneri (DSM 4782), L. monocytogenes (NCTC1194), L. innocua (NCTC 11288), and A. salmonicida (CECT 894) were purchased from the ATCC, DSM, NCTC, and CECT collections, respectively. Bioluminescent E. coli was used in previous works [71]. A. caviae CECT 838, A. hydrophila 839 and Aeromonas IR13 were isolated using water from the Vouga river [72]. Fresh plate bacterial cultures were kept in 
solid Tryptic Soy Agar medium (TSA; Liofilchem, Roseto degli Abruzzi, Italy) at $4{ }^{\circ} \mathrm{C}$. Prior to each essay, one isolated colony was aseptically transferred to $10 \mathrm{~mL}$ of TSB (Liofilchem, Roseto degli Abruzzi, Italy) and was grown overnight at $25^{\circ} \mathrm{C}$ or $37^{\circ} \mathrm{C}$. An aliquot of this culture $(100 \mu \mathrm{L})$ was aseptically transferred to $10 \mathrm{~mL}$ of fresh TSB medium and grown overnight at $25^{\circ} \mathrm{C}$ or $37^{\circ} \mathrm{C}$ to hit an optical density (O.D. 600) of 0.8 , corresponding to around $10^{9}$ cells for $\mathrm{mL}$.

\subsection{Phage Isolation and Purification}

Phages AH-1, AH-4, and AH-5 were isolated from sewage water samples collected in the sewage network of Aveiro (SIMRIA Multi Sanitation System of Ria de Aveiro-station EEIS9) gathered at different times. One hundred millilitres of water was filtered through $0.45 \mu \mathrm{m}$ pore size polycarbonate membranes (Millipore, Bedford, MA, USA). Filtered water was added to $100 \mathrm{~mL}$ of a twice concentrated TSB medium with $1 \mathrm{~mL}$ of a fresh culture of the host, $A$. hydrophila (ATCC 7966). The mixtures were incubated at $25^{\circ} \mathrm{C}$ for $18 \mathrm{~h}$ at $80 \mathrm{rpm}$, and afterwards centrifuged at $10,000 \times \mathrm{g}$ for $10 \mathrm{~min}$ at $4{ }^{\circ} \mathrm{C}$ and filtered through a polyethersulphate layer with a $0.22 \mu \mathrm{m}$ pore size (Merck-Millipore, Darmstadt, Germany). Suspensions were stored at $4{ }^{\circ} \mathrm{C}$ and the titer was determined by the double-layer agar method [73]. Successive dilutions of the suspensions were done in phosphate-cradled saline (PBS) $\left[137 \mathrm{mmol}^{-1} \mathrm{NaCl}\right.$ (Sigma, St. Louis, MO, USA), $8.1 \mathrm{mmol}^{-1} \mathrm{Na}_{2} \mathrm{HPO}_{4} \cdot 2 \mathrm{H}_{2} \mathrm{O}$ (Sigma, St. Louis MO, USA), $2.7 \mathrm{mmol}^{-1} \mathrm{KCl}$ (Sigma, St. Louis, MO, USA), and $1.76 \mathrm{mmol}^{-1}$ $\mathrm{KH}_{2} \mathrm{PO}_{4}$ (Sigma, St. Louis, MO, USA), pH 7.4). $500 \mu \mathrm{L}$ of each dilution, along with $200 \mu \mathrm{L}$ of fresh bacterial culture, were mixed in $5 \mathrm{~mL}$ of TSB $0.6 \%$ top agar layer [30 g/L TSB (Liofilchem, Roseto degli Abruzzi, Italy), $6 \mathrm{~g} / \mathrm{L}$ agar (Liofilchem, Roseto degli Abruzzi, Italy), $0.12 \mathrm{~g} / \mathrm{L} \mathrm{MgSO}_{4}$ (Sigma, St. Louis, MO, USA), and $0.05 \mathrm{~g} / \mathrm{L} \mathrm{CaCl}_{2}$ (Sigma, St. Louis, $\mathrm{MO}, \mathrm{USA}), \mathrm{pH} 7.4]$ and poured over a TSA plate. Plates were incubated at $25^{\circ} \mathrm{C}$ and observed for the presence of lytic plaques after $12 \mathrm{~h}$. One single plaque was selected from the agar and added to TSB medium with a fresh culture of the host. The sample was centrifuged, being the supernatant used as a phage source for a second isolation procedure. Three successive single-plaque isolation cycles were performed in order to acquire pure phage stocks. All lysates were centrifuged at $10,000 \times g$ for $10 \mathrm{~min}$ at $4{ }^{\circ} \mathrm{C}$, to remove bacteria or bacterial debris. The phage suspensions were kept at $4{ }^{\circ} \mathrm{C}$.

Phage stocks were prepared using $A$. hydrophila as the host. Phage stocks were prepared from the phage suspensions purified in SM buffer $(0.1 \mathrm{M} \mathrm{NaCl}$ (Sigma-Aldrich, St. Louis, MO, USA), $20 \mathrm{mM}$ Tris-HCl (Sigma, St. Louis, MO, USA), and $8 \mathrm{mM} \mathrm{MgSO}_{4}$ (Sigma, St. Louis, MO, USA), pH 7.5). After incubation, the stock culture of A. hydrophila in the exponential growth phase was centrifuged at $10,000 \times g$ for $10 \mathrm{~min}$ and the pellet was resuspended in $30 \mathrm{~mL}$ of SM buffer. Then, three hundred microliters of the phage stock were added to $30 \mathrm{~mL}$ of SM buffer with bacteria. The phage stocks were incubated at $25^{\circ} \mathrm{C}$ under an orbital shaking set at $50 \mathrm{rpm}$. The lysate was centrifuged at $10,000 \times g$ for $10 \mathrm{~min}$ at $4{ }^{\circ} \mathrm{C}$ and the supernatant was filtered through a polyethersulphate membrane with a $0.22 \mu \mathrm{m}$ pore size (Merck-Millipore, Darmstadt, Germany). The phage suspension was stored at $4{ }^{\circ} \mathrm{C}$ until and the titer was determined via the double-layer agar method [73] as described above. The plates were incubated at $25^{\circ} \mathrm{C}$ for $12 \mathrm{~h}$ and the number of lysis plaques was counted. The results were expressed as plaque-forming units per millilitre (PFU/mL).

\subsection{Electron Microscope Examination}

Phage particles from high titter stock suspensions $\left(10^{10} \mathrm{PFU} / \mathrm{mL}\right)$ were negatively stained with 2\% uranyl acetate (Electron Microscopy Sciences, Hatfield, UK) and subjected to electron micrographs using a JEOL 1011 transmission electron microscope (JEDL USA Inc., Peabody, MA, USA) operating at $100 \mathrm{kV}$. The images were obtained with a Gatan CCD-Erlangshen ES100W. 


\subsection{Phage Host Range and Efficiency of Plating (EOP) Analysis}

Spot testing according to the procedure described by [73], was done in order to assess the phage's host range, using the bacterial strains listed in Table 1. Five millilitres of TSB $0.6 \%$ agar, inoculated with $300 \mu \mathrm{L}$ of fresh bacterial culture, was overlaid on solid TSA and spotted with $10 \mu \mathrm{L}$ of the phage suspension. The plates were incubated at $25^{\circ} \mathrm{C}$ and observed for the presence of lysis plaques after $12 \mathrm{~h}$. A clear lysis zone at the spot determined bacterial sensitivity to the phage. Bacteria were differentiated according to either a clear lysis zone $(+)$ or no lysis zone $(-)$ (Table 1$)$, depending on the clarity of the spot. Bacteria with positive spot tests (occurrence of clear lysis zone) were subjected to EOP using the double-layer agar method [73], as described before. The plates were incubated at $25^{\circ} \mathrm{C}$ and observed for the presence of plaques after $12 \mathrm{~h}$. The EOP for each bacterial host was calculated by comparison with the efficacy of A. hydrophila (host) (Table 1) and was calculated as (average PFU on target bacteria/average PFU on host bacteria) $\times 100$ [74] The EOP value obtained with the host strain was considered as EOP $=100 \%$, and all values are presented in the manuscript as the mean of three independent measurements followed by their standard deviation.

\subsection{One Step Growth Assays}

Phage AH-1, AH-4, or AH-5 suspension (with a final concentration of $10^{6} \mathrm{PFU} / \mathrm{mL}$ ) was added to $10 \mathrm{~mL}$ of a fresh bacterial culture of $A$. hydrophila (with a final concentration of $10^{9} \mathrm{CFU} / \mathrm{mL}$ ) to have an MOI of 0.001 and the resulting suspension was incubated without shaking for $5 \mathrm{~min}$ at $25^{\circ} \mathrm{C}$ [51]. The suspension was then centrifuged at $10,000 \times g$ for $5 \mathrm{~min}$, the supernatant was discarded, and the pellet was resuspended in $10 \mathrm{~mL}$ of TSB and incubated at $25^{\circ} \mathrm{C}$. Samples of $1 \mathrm{~mL}$ were collected at time 0 and every $10 \mathrm{~min}$ up to $150 \mathrm{~min}$ of incubation and then immediately tittered by the double-layer agar method [73]. The plates were incubated at $25^{\circ} \mathrm{C}$ and observed for plaques after $18 \mathrm{~h}$. Three independent assays were performed.

\subsection{Bacterial Kill Curves Using Single-Phage Suspensions and Phage Cocktails}

Bacterial inactivation was determined using single phage suspensions (AH-1, $\mathrm{AH}-4$, and AH-5) and phage cocktails (AH-1/AH-4, AH-1/AH-5, AH-4/AH-5, and AH-1/AH-4/ $\mathrm{AH}-5$; two or all phages were mixed with each phage at the same concentration) using the bacterium A. hydrophila at an MOI of 1 . To obtain an MOI of 1, the exponential cultures of bacteria (final concentration of $10^{5} \mathrm{CFU} / \mathrm{mL}$ ) and phage suspension (final concentration of $10^{5} \mathrm{PFU} / \mathrm{mL}$ ) were inoculated in sterilized glass erlenmeyers with $30 \mathrm{~mL}$ of TSB medium and incubated at $25{ }^{\circ} \mathrm{C}$ without agitation $(\mathrm{B}+\mathrm{P})$. The phage titre was determined in triplicate by the double-layer agar method [73] after an incubation period of $12 \mathrm{~h}$ at $25^{\circ} \mathrm{C}$. Bacterial concentration was determined in triplicate in solid TSA medium through the dropplate method after an incubation period of $24 \mathrm{~h}$ at $25^{\circ} \mathrm{C}$. Three independent experiments were performed for each condition.

\subsection{Rate of Emergence of Bacterial Mutants Resistant to Phages}

The development of $A$. hydrophila mutants, resistant to phages AH-1, AH-4, and AH-5, and phage cocktails $\mathrm{AH}-1 / \mathrm{AH}-4, \mathrm{AH}-1 / \mathrm{AH}-5, \mathrm{AH}-4 / \mathrm{AH}-5$, and $\mathrm{AH}-1 / \mathrm{AH}-4 / \mathrm{AH}-5$ was evaluated according to the procedure described by Filippov et al. (2011) [57]. In order to determine the frequency of phage-resistant bacteria, ten isolated colonies from a plate with sensitive bacteria were selected and inoculated into ten tubes with $5 \mathrm{~mL}$ of TSB medium and grown at $25^{\circ} \mathrm{C}$ for $24 \mathrm{~h}$ (concentration around $10^{9} \mathrm{CFU} / \mathrm{mL}$ ). Aliquots of $100 \mu \mathrm{L}$ from the $10^{0}$ to $10^{-2}$ dilutions of the bacterial culture and aliquots of $100 \mu \mathrm{L}$ of the phage from a stock solution of $10^{9} \mathrm{PFU} / \mathrm{mL}$ were inoculated into tubes containing TSB $0.6 \%$ agar, plated on TSA plates, and incubated at $25^{\circ} \mathrm{C}$ for $3-5$ days (since some of the phage-resistant mutants may grow slowly). Simultaneously, $100 \mu \mathrm{L}$ aliquots of $10^{-5}$ to $10^{-7}$ dilutions of the bacterial culture were plated by incorporation on TSA plates without phage and incubated at $25^{\circ} \mathrm{C}$ for $24 \mathrm{~h}$. The calculation of the frequency of $A$. hydrophila 
spontaneous phage-resistant mutants was done by dividing the number of resistant bacteria (obtained from the bacteria grown in the presence of phage particles) by the total number of sensitive bacteria (prepared from the culture without phages) [57]. Three independent assays were performed.

Sensitive and phage AH-1-resistant colonies (phage AH-1 was selected for this experiment because it was the most efficient phage to control $A$. hydrophila) were picked up and purified by successive sub-culturing in TSA to remove attached phage particles and were used in further experiments (see Section 4.8).

A spot test on double agar plates was used to confirm the phage AH-1 resistance to phage-resistant strains and phage susceptibility of natural variant clones. To evaluate phages AH-4 and AH-5 sensitivity to phage AH-1-resistant strains, the spot test procedure was used. To confirm that the resistance of the bacterial isolates was stable through generations, the strains were passed through 10 consecutive subcultures in a liquid medium. Samples were taken from each subculture to assess bacterial resistance against phage infection using the double agar method.

\subsection{Growth Curve of Phage-Resistant A. hydrophila Strains}

To evaluate the growth of the ten AH-1-resistant bacteria and the ten natural variants, these and their parent strains were cultured in parallel on a 96 well plate with TSB medium at $25^{\circ} \mathrm{C}$. This phage was selected for these experiments because was the most efficient phage to control A. hydrophila. The O.D.600 nm of the cultures was measured at 0, 2, 4, 6, $8,10,12$, and $24 \mathrm{~h}$ using a microplate photometer (Multiskan FC, Thermo Fischer). Three independent experiments were performed for each condition.

\subsection{Bacterial Kill Curves at Different MOIs}

A. hydrophila (with a final concentration of $10^{5} \mathrm{CFU} / \mathrm{mL}$ ) inactivation by the phage AH-1 (final concentrations of $10^{5}, 10^{6}, 10^{7}$ and $10^{8} \mathrm{PFU} / \mathrm{mL}$ ) was evaluated at MOI 1, 10, 100 and MOI 1000.

For each assay, two controls were included: the bacterial control (BC) and the phage control (PC). The bacterial controls were only inoculated with $A$. hydrophila and the phage controls were only inoculated with the phage suspensions. Controls and test samples (BP, bacteria plus phage) were incubated exactly in the same conditions and aliquots were collected at time 0 and after 2, 4, 6, 8, 10, and $12 \mathrm{~h}$ of incubation. In all assays, the phage titre was determined in triplicate by the double-layer agar method [73] after a $12 \mathrm{~h}$ incubation at $25^{\circ} \mathrm{C}$. Bacterial concentration was determined in triplicate in solid TSA medium through the drop-plate method after a $24 \mathrm{~h}$ incubation at $25^{\circ} \mathrm{C}$. Three independent assays were performed for each condition.

\subsection{Phage Application during Cerastoderma edule Depuration in Static Seawater 4.10.1. Collection of C. edule Samples}

Cockles were selected as biological models to test the efficacy of phage biocontrol against $A$. hydrophila and were purchased from Mar de Sensações Lda. (Gafanha da Nazaré, Portugal), a bivalve wholesaler, after being depurated according to industrial processing protocols ( $48 \mathrm{~h}$ at $15-16^{\circ} \mathrm{C}$ in seawater irradiated with UV-C).

Live cockles were transported to the laboratory in a container with seawater with controlled temperature $\left(16 \pm 1^{\circ} \mathrm{C}\right)$, under an oxygen saturated atmosphere. Experiments were performed no more than 30 min post-collection.

4.10.2. Depuration of Artificially Contaminated Cockles in the Presence of Phage AH-1 in a Static System

The efficacy of phage AH-1 (selected according to the results of the tests described above) was evaluated during depuration in a static system.

Cockles were kept in independent tanks $(10 \mathrm{~cm}$ length $\times 9 \mathrm{~cm}$ width $\times 15 \mathrm{~cm}$ height), acting as a static system, filled with $0.6 \mathrm{~L}$ of sterile synthetic seawater [prepared by mixing 
a synthetic salt brand (Tropic Marin Pro Reef salt-TropicMarine, Wartenberg, Germany) with water purified by a reverse osmosis system (Aqua-win RO-6080, Kaohsiung, Taiwan) and then filtered through a $0.2 \mu \mathrm{m}$ membrane (Millipore, Bedford, MA, USA)] and equipped with an aerator for $12 \mathrm{~h}$ before being infected with $A$. hydrophila. The temperature was maintained at $16 \pm 1{ }^{\circ} \mathrm{C}, \mathrm{pH}$ at $8.0 \pm 0.2$, salinity at 35 , and dissolved oxygen above $5.5 \mathrm{mg} / \mathrm{L}$ during the experiment. After the adaptation period, cockles were washed with synthetic seawater and placed in independent tanks filled with synthetic seawater. The concentration of Aeromonas in cockles was determined before the decontamination procedure using the specific medium Glutamate Starch Phenol Red Agar (GSP, Liofilchem, Roseto degli Abruzzi, Italy). However, during the depuration of artificially contaminated cockles, the bacterial reduction was only evaluated by determining the concentration of cultivable bacteria. Three cockles were randomly selected from each tank, weighing about ten grams each. The flesh and intra-valvular liquid (FIL) of the cockles were pooled, blended in $90 \mathrm{~mL}$ of alkaline peptone water (Liofilchem, Roseto degli Abruzzi, Italy) and homogenized in a Bag Mixer 400 (Interscience, Saint Nom la Brétèche, France). The homogenized samples were then serially diluted ten-fold and $1 \mathrm{~mL}$ from each dilution was spread on both GSP and TSA plates. All plates were incubated at $25^{\circ} \mathrm{C}$ for $24 \mathrm{~h}$.

A total of 4 groups of cockles were randomly formed, each group containing three replicates of 24 animals ( 24 specimens $/$ tank $\times 4$ groups $\times 3$ replicates $=288$ cockles). A. hydrophila was added to 2 of the 4 groups to obtain a final concentration of $10^{5} \mathrm{CFU} / \mathrm{mL}$. In the other 2 groups, no $A$. hydrophila was added. Cockles from the 4 groups remained for $12 \mathrm{~h}$ in the tanks under the same conditions. Following $12 \mathrm{~h}$ of incubation, cockles were washed with sterilized artificial seawater and placed in clean tanks with no A. hydrophila contamination. From the 2 groups of cockles infected with $A$. hydrophila, 1 was inoculated with phage AH-1 (final concentration of $10^{5} \mathrm{PFU} / \mathrm{mL}$ ) at an MOI of 1 (test tanks-BP), while the remaining group was not inoculated with any phage (bacteria control- $\mathrm{BC}$ ). Concerning the 2 groups of cockles not infected with A. hydrophila, one of them was inoculated with phage AH-1 (phage control-PC) and the remaining group was not inoculated with the phage (cockle control-CC). All 4 groups were incubated exactly under the same conditions. Cockles of test tanks and controls were sampled at time 0 and 3, 6 and $12 \mathrm{~h}$ after phage addition. At each sampling time, three cockles were randomly selected from each tank, weighing about ten grams each. The flesh and intra-valvular liquid (FIL) of the cockles were pooled, blended in $90 \mathrm{~mL}$ of alkaline peptone water (Liofilchem, Roseto degli Abruzzi, Italy), and homogenized in a Bag Mixer 400 (Interscience, Saint Nom la Brétèche, France). The homogenized samples were then serially diluted ten-fold and $1 \mathrm{~mL}$ from each dilution was spread on the non-specific TSA plates. All plates were incubated at $25^{\circ} \mathrm{C}$ for $24 \mathrm{~h}$. The counts in the TSA medium allowed the detection of the added A. hydrophila, as well as other cultivable bacteria that were already present in cockles. Phage titer was determined in duplicate using the double-agar layer technique [73] after an incubation period of $12 \mathrm{~h}$ at $25^{\circ} \mathrm{C}$. Three independent experiments were performed in different periods to secure independent replication.

\subsection{Statistical Analysis}

The statistical analysis of data was performed using the GraphPad Prism software 6.01, San Diego, California, USA. Normal distribution of the data was checked by a Kolmogorov-Smirnov test and the homogeneity of variance was assessed by Levene's test. The significance of bacterial and viral concentrations between the treatments and during the experiments was tested using two-way ANOVA with repeated measures and Tukey's multiple comparison post-hoc test (Sections 2.5, 2.8 and 2.9). For different treatments, the significance of differences was evaluated by comparing the result obtained in the test samples with the results obtained for the correspondent control samples, for the different times. Two-way ANOVA was used to analyse the statistical differences between the growth curves of the sensitive and the phage-resistant bacteria during the sampling time (Section 2.7). A value of $p<0.05$ was considered to be statistically significant. 


\section{Conclusions}

In the present work, all phages efficiently inactivated the pathogenic bacterium A. hydrophila while inducing a low frequency of phage-resistant bacterial mutants during in vitro applications. Furthermore, phage AH-1 successfully improved the efficiency of depuration in a static water system. The results of this study provide further evidence that phages can safely inactivate pathogenic bacteria and may be successfully combined with industrial practices already used to improve their efficacy.

Author Contributions: J.D., C.P. and P.C. performed the experiments; J.D. and C.P. wrote the paper, and P.C. also contributed to the writing; A.A. supervised the work, revised the paper, and contributed with reagents and analysis tools. All authors have read and agreed to the published version of the manuscript.

Funding: This research received no external funding.

Institutional Review Board Statement: Ethical review and approval were waived for this study, due to the use of invertebrate animals.

Informed Consent Statement: Not applicable.

Data Availability Statement: Data is contained within the article.

Acknowledgments: Thanks are due to FCT/MCTES for the financial support to CESAM (UID/AMB / $50017 / 2019)$, through national funds. Carla Pereira was supported by a Junior Research contract (CEEC Individual/03974/2017) and Pedro Costa was supported by a PhD grant (PD/BD/150360/2019) financed by the Portuguese Foundation for Science and Technology (FCT). Thanks are also due to the Department of Biology and University of Aveiro where this research work was carried out.

Conflicts of Interest: The authors declare no conflict of interest.

\section{References}

1. Oliveira, J.; Cunha, A.; Castilho, F.; Romalde, J.; Pereira, M. Microbial contamination and purification of bivalve shellfish: Crucial aspects in monitoring and future perspectives-A mini-review. Food Control. 2011, 22, 805-816. [CrossRef]

2. FAO. The State of World Fisheries and Aquaculture 2020. Sustainability in Action; FAO: Rome, Italy, 2020.

3. Pereira, C.; Costa, P.; Duarte, J.; Balcão, V.M.; Almeida, A. Phage therapy as a potential approach in the biocontrol of patho-genic bacteria associated with shellfish consumption. Int. J. Food Microbiol. 2021, 338, 108995. [CrossRef] [PubMed]

4. Zannella, C.; Mosca, F.; Mariani, F.; Franci, G.; Folliero, V.; Galdiero, M.; Tiscar, P.G.; Galdiero, M. Microbial Diseases of Bivalve Mollusks: Infections, Immunology and Antimicrobial Defense. Mar. Drugs 2017, 15, 182. [CrossRef] [PubMed]

5. Fernández, E.; Alvarez-Salgado, X.A.; Beiras, R.; Ovejero, A.; Méndez, G. Coexistence of urban uses and shellfish production in an upwelling-driven, highly productive marine environment: The case of the Ría de Vigo (Galicia, Spain). Reg. Stud. Mar. Sci. 2016, 8, 362-370. [CrossRef]

6. Butt, A.A.; Aldridge, K.E.; Sanders, C. V Infections related to the ingestion of seafood Part I: Viral and bacterial infections. Lancet Infect. Dis. 2004, 4, 201-212. [CrossRef]

7. De Silva, B.C.J.; Hossain, S.; Dahanayake, P.S.; Lee, D.-W.; Wickramanayake, M.V.K.S.; Heo, G.-J. Multi-drug resistant mes-ophilic aeromonads isolated from marketed scallops (Patinopecten yessoensis) harboring resistance genes. Fish. Aquat. Life 2020, $28,1-10$. [CrossRef]

8. Silva, A.C.M.d.M.; Nascimento, D.L.; Machado, R.Z.; Costa, F.N. Caracterização de Aeromonas spp isoladas de amostras de ostras e água por método microbiológico e molecular. Ciência Anim. Bras. 2014, 15, 362-368. [CrossRef]

9. Chittick, B.; Stoskopf, M.; Law, M.; Overstreet, R.; Levine, J. Evaluation of potential health risks to Eastern Elliptio (Elliptio complanata) (Mollusca: Bivalvia: Unionida: Unionidae) and implications for sympatric endangered freshwater mussel species. J. Aquat. Ecosyst. Stress Recover. 2001, 9, 35-42. [CrossRef]

10. Ribeiro, E.B.; Noleto, K.S.; de Oliveira, S.R.S.; de Jesus, W.B.; de Sousa Serra, I.M.R.; da Silva de Almeida, Z.; de Oliveira Mota Andrade, T.; de Araújo Soares, R.; Antonio, Í.G.; Santos, D.M.S.; et al. Biomarkers (glutathione S-transferase and catalase) and microorganisms in soft tissues of Crassostrea rhizophorae to assess contamination of seafood in Brazil. Mar. Pollut. Bull. 2020, 158, 111348. [CrossRef]

11. Krovacek, K.; Dumontet, S.; Eriksson, E.; Baloda, S.B. Isolation, and virulence profiles, of Aeromonas hydrophila implicated in an outbreak of food poisoning in Sweden. Microbiol. Immunol. 1995, 39, 655-661. [CrossRef]

12. Grim, C.J.; Kozlova, E.V.; Ponnusamy, D.; Fitts, E.C.; Sha, J.; Kirtley, M.L.; van Lier, C.J.; Tiner, B.L.; Erova, T.E.; Joseph, S.J.; et al. Functional genomic characterization of virulence factors from necrotizing fasciitis-causing strains of Aeromonas hydrophila. Appl. Environ. Microbiol. 2014, 80, 4162-4183. [CrossRef] [PubMed] 
13. Martinez-Albores, A.; Lopez-Santamarina, A.; Rodriguez, J.A.; Ibarra, I.S.; Mondragón, A.D.C.; Miranda, J.M.; Lamas, A.; Cepeda, A. Complementary methods to improve the depuration of bivalves: A review. Foods 2020, 9, 129. [CrossRef] [PubMed]

14. Polo, D.; Álvarez, C.; Díez, J.; Darriba, S.; Longa, Á.; Romalde, J.L. Viral elimination during commercial depuration of shellfish. Food Control 2014, 43, 206-212. [CrossRef]

15. Anjana, S.; Abhilash, S.; Varghese, B.; Sabu, S.; Sunooj, K.; Xavier, K.M. Performance evaluation of ultra violet assisted vertical re-circulating depuration system on microbial, heavy metal reduction and composition of black clam (Villorita cyprinoides). LWT 2021, 138, 110628. [CrossRef]

16. Lee, R.; Lovatelli, A.; Ababouch, L. Bivalve Depuration: Fundamental and Practical Aspects; FAO Fisheries Technical Paper; FAO: Rome, Italy, 2008; ISBN 978-92-5-106006-3.

17. Groubert, T.N.; Oliver, J.D. Interaction of Vibrio vulnificus and the Eastern Oyster, Crassostrea virginica. J. Food Prot. 1994, 57, 224-228. [CrossRef]

18. Martínez, O.; Rodríguez-Calleja, J.M.; Santos, J.; Otero, A.; García-López, M.L. Foodborne and indicator bacteria in farmed molluscan shellfish before and after depuration. J. Food Prot. 2009, 72, 1443-1449. [CrossRef]

19. Rong, R.; Lin, H.; Wang, J.; Khan, M.N.; Li, M. Reductions of Vibrio parahaemolyticus in oysters after bacteriophage application during depuration. Aquaculture 2014, 418-419, 171-176. [CrossRef]

20. Tamplin, M.L.; Capers, G.M. Persistence of Vibrio vulnificus in tissues of Gulf Coast oysters, Crassostrea virginica, exposed to seawater disinfected with UV light. Appl. Environ. Microbiol. 1992, 58, 1506-1510. [CrossRef]

21. Vezzulli, L.; Stagnaro, L.; Grande, C.; Tassistro, G.; Canesi, L.; Pruzzo, C. Comparative 16SrDNA Gene-based microbiota profiles of the Pacific oyster (Crassostrea gigas) and the Mediterranean mussel (Mytilus galloprovincialis) from a shellfish farm (Ligurian Sea, Italy). Microb. Ecol. 2017, 75, 495-504. [CrossRef]

22. WHO; Lees, D.; Younger, A.; Dore, B. World Health Organization (WHO) Depuration and Relaying; Rees, G., Pond, K., Kay, D., Bartram, J., Santo Domingo, J., Eds.; IWA Publishing: London, UK, 2010; ISBN 9781843392255.

23. Clokie, M.R.J.; Millard, A.D.; Letarov, A.V.; Heaphy, S. Phages in nature. Bacteriophage 2011, 1, 31-45. [CrossRef]

24. Galarce, N.E.; Bravo, J.L.; Robeson, J.P.; Borie, C.F. Bacteriophage cocktail reduces Salmonella enterica serovar Enteritidis counts in raw and smoked salmon tissues. Rev. Argent. Microbiol. 2014, 46, 333-337. [CrossRef]

25. Almeida, A.; Cunha, Â.; Gomes, N.C.; Alves, E.; Costa, L.; Faustino, M.A. Phage therapy and photodynamic therapy: Low environmental impact approaches to inactivate microorganisms in fish farming plants. Mar. Drugs 2009, 7, 268-313. [CrossRef]

26. Jun, J.W.; Kim, H.J.; Kil Yun, S.; Chai, J.Y.; Park, S.C. Eating oysters without risk of vibriosis: Application of a bacteriophage against Vibrio parahaemolyticus in oysters. Int. J. Food Microbiol. 2014, 188, 31-35. [CrossRef] [PubMed]

27. Pereira, C.; Moreirinha, C.; Rocha, R.J.; Calado, R.; Romalde, J.L.; Nunes, M.L.; Almeida, A. Application of bacteriophages during depuration reduces the load of Salmonella typhimurium in cockles. Food Res. Int. 2016, 90, 73-84. [CrossRef] [PubMed]

28. Pereira, C.; Moreirinha, C.; Teles, L.; Rocha, R.J.; Calado, R.; Romalde, J.L.; Nunes, M.L.; Almeida, A. Application of phage therapy during bivalve depuration improves Escherichia coli decontamination. Food Microbiol. 2017, 61, 102-112. [CrossRef]

29. Akmal, M.; Rahimi-Midani, A.; Hafeez-Ur-Rehman, M.; Hussain, A.; Choi, T.-J. Isolation, characterization, and application of a bacteriophage infecting the fish pathogen Aeromonas hydrophila. Pathogens 2020, 9, 215. [CrossRef]

30. Aberoum, A.; Jooyandeh, H. A Review on occurrence and characterization of the Aeromonas species from marine fishes. World J. Fish Mar. Sci. 2010, 2, 519-523.

31. ChiHsin, H.; ChongYi, L.; JongKang, L.; ChanShing, L. Control of the eel (Anguilla japonica) pathogens, Aeromonas hydrophila and Edwardsiella tarda, by bacteriophages. J. Fish. Soc. Taiwan 2000, 27, 21-31.

32. Wu, J.-L.; Lin, H.-M.; Jan, L.; Hsu, Y.-L.; Chang, L.-H. Biological control of fish bacterial pathogen, Aeromonas hydrophila, by Bbcteriophage AH 1. Fish Pathol. 1981, 15, 271-276. [CrossRef]

33. Jun, J.W.; Kim, J.H.; Shin, S.P.; Han, J.E.; Chai, J.Y.; Park, S.C. Protective effects of the Aeromonas phages pAh1-C and pAh6-C against mass mortality of the cyprinid loach (Misgurnus anguillicaudatus) caused by Aeromonas hydrophila. Aquaculture 2013, 416-417, 289-295. [CrossRef]

34. Hassan, S.W.; Ali, S.M.; Almisherfi, M.M. Isolation and molecular characterization of some marine Aeromonas phages: Protective effects for Nile tilapia infected with Aeromonas hydrophila. J. Pure Appl. Microbiol. 2018, 12, 1175-1185. [CrossRef]

35. Hoang, H.A.; Xuan, T.T.T.; Nga, L.P.; Oanh, D.T.H. Selection of phages to control Aeromonas hydrophila-An infectious agent in striped catfish. Biocontrol Sci. 2019, 24, 23-28. [CrossRef] [PubMed]

36. El-araby, D.; El-didamony, G.; Th, M.M. New approach to use phage therapy against Aeromonas hydrophila induced motile Aeromonas septicemia in Nile tilapia. Mar. Sci. Res. Dev. 2016, 6, 6-11.

37. Chow, M.S.; Rouf, M.A. Isolation and partial characterization of two Aeromonas hydrophila bacteriophages. Appl. Environ. Microbiol. 1983, 45, 1670-1676. [CrossRef] [PubMed]

38. Wang, J.B.; Lin, N.T.; Tseng, Y.H.; Weng, S.F. Genomic characterization of the novel Aeromonas hydrophila phage ahp1 suggests the derivation of a new subgroup from phiKMV-Like family. PLoS ONE 2016, 11, e0162060. [CrossRef] [PubMed]

39. Kabwe, M.; Brown, T.; Speirs, L.; Ku, H.; Leach, M.; Chan, H.T.; Petrovski, S.; Lock, P.; Tucci, J. Novel bacteriophages capable of disrupting biofilms from clinical strains of Aeromonas hydrophila. Front. Microbiol. 2020, 11, 194. [CrossRef]

40. Le, T.S.; Nguyen, T.H.; Vo, H.P.; Doan, V.C.; Nguyen, H.L.; Tran, M.T.; Tran, T.T.; Southgate, P.C.; İpek Kurtböke, D. Protective effects of bacteriophages against Aeromonas hydrophila species causing Motile Aeromonas Septicemia (MAS) in striped catfish. Antibiotics 2018, 7, 16. [CrossRef] 
41. Schulz, P.; Robak, S.; Dastych, J.; Siwicki, A.K. Influence of bacteriophages cocktail on European eel (Anguilla anguilla) im-munity and survival after experimental challenge. Fish Shellfish Immunol. 2019, 84, 28-37. [CrossRef]

42. Schulz, P.; Pajdak-Czaus, J.; Robak, S.; Dastych, J.; Siwicki, A.K. Bacteriophage-based cocktail modulates selected immuno-logical parameters and post-challenge survival of rainbow trout (Oncorhynchus mykiss). J. Fish Dis. 2019, 42, 1151-1160. [PubMed]

43. Liu, J.; Gao, S.; Dong, Y.; Lu, C.; Liu, Y. Isolation and characterization of bacteriophages against virulent Aeromonas hydrophila. BMC Microbiol. 2020, 20, 1-13. [CrossRef]

44. Pereira, C.; Moreirinha, C.; Lewicka, M.; Almeida, P.; Clemente, C.; Cunha, Â.; Delgadillo, I.; Romalde, J.; Nunes, M.L.; Al-meida, A. Bacteriophages with potential to inactivate Salmonella typhimurium: Use of single phage suspensions and phage cocktails. Virus Res. 2016, 220, 179-192. [CrossRef]

45. Costa, P.; Pereira, C.; Gomes, A.T.P.C.; Almeida, A. Efficiency ofsingle phage suspensions and phage cocktail in the inactivation of Escherichia coli and Salmonella typhimurium: An in vitro preliminary study. Microorganisms 2019, 7, 94. [CrossRef]

46. Pereira, C.; Silva, Y.J.; Santos, A.L.; Cunha, Â.; Gomes, N.C.M.; Almeida, A. Bacteriophages with potential for inactivation of fish pathogenic bacteria: Survival, host specificity and effect on bacterial community structure. Mar. Drugs 2011, 9, $2236-2255$. [CrossRef]

47. Mirzaei, K.M.; Nilsson, A.S. Isolation of phages for phage therapy: A comparison of spot tests and efficiency of plating analyses for determination of host range and efficacy. PLoS ONE 2015, 10, e0118557. [CrossRef]

48. Børsheim, K. Native marine bacteriophages. FEMS Microbiol. Ecol. 1993, 102, 141-159. [CrossRef]

49. Kellogg, C.; Rose, J.; Jiang, S.; Thurmond, J.; Paul, J. Genetic diversity of related vibriophages isolated from marine environments around Florida and Hawaii, USA. Mar. Ecol. Prog. Ser. 1995, 120, 89-98. [CrossRef]

50. Wichels, A.; Biel, S.S.; Gelderblom, H.R.; Brinkhoff, T.; Muyzer, G.; Schütt, C. Bacteriophage diversity in the North Sea. Appl. Environ. Microbiol. 1998, 64, 4128-4133. [CrossRef]

51. Mateus, L.; Costa, L.; Silva, Y.; Pereira, C.; Cunha, A.; Almeida, A. Efficiency of phage cocktails in the inactivation of Vibrio in aquaculture. Aquaculture 2014, 424-425, 167-173. [CrossRef]

52. Abedon, S.T.; Culler, R.R. Optimizing bacteriophage plaque fecundity. J. Biol. 2007, 249, 582-592. [CrossRef] [PubMed]

53. Abedon, S.T. Lysis from without. Bacteriophage 2011, 1, 46-49. [CrossRef]

54. Drulis-Kawa, Z.; Majkowska-Skrobek, G.; Maciejewska, B.; Delattre, A.-S.; Lavigne, R. Learning from bacteriophages - Advantages and limitations of phage and phage-encoded protein applications. Curr. Protein Pept. Sci. 2012, 13, 699-722. [CrossRef]

55. Bull, J.J.; Gill, J.J. The habits of highly effective phages: Population dynamics as a framework for identifying therapeutic phages. Front. Microbiol. 2014, 5, 618. [CrossRef]

56. Duarte, J.; Pereira, C.; Moreirinha, C.; Salvio, R.; Lopes, A.; Wang, D.; Almeida, A. New insights on phage efficacy to control Aeromonas salmonicida in aquaculture systems: An in vitro preliminary study. Aquaculture 2018, 495, 970-982. [CrossRef]

57. Filippov, A.; Sergueev, K.V.; He, Y.; Huang, X.Z.; Gnade, B.T.; Mueller, A.J.; Fernandez-Prada, C.; Nikolich, M.P. Bacteriophage-resistant mutants in Yersinia pestis: Identification of phage receptors and attenuation for mice. PLoS ONE 2011, 6, 1-11. [CrossRef]

58. Pereira, S.; Pereira, C.; Santos, L.; Klumpp, J.; Almeida, A. Potential of phage cocktails in the inactivation of Enterobacter cloacae —An in vitro study in a buffer solution and in urine samples. Virus Res. 2016, 211, 199-208. [CrossRef] [PubMed]

59. Pereira, C.; Moreirinha, C.; Lewicka, M.; Almeida, P.; Clemente, C.; Romalde, J.L.; Nunes, M.L.; Almeida, A. Characterization and in vitro evaluation of new bacteriophages for the biocontrol of Escherichia coli. Virus Res. 2017, 227, 171-182. [CrossRef] [PubMed]

60. O'Flynn, G.; Ross, R.P.; Fitzgerald, G.F.; Coffey, A. Evaluation of a cocktail of three bacteriophages for biocontrol of Escherichia coli O157:H7. Appl. Environ. Microbiol. 2004, 70, 3417-3424. [CrossRef]

61. Tanji, Y.; Shimada, T.; Yoichi, M.; Miyanaga, K.; Hori, K.; Unno, H. Toward rational control of Escherichia coli O157:H7 by a phage cocktail. Appl. Microbiol. Biotechnol. 2004, 64, 270-274. [CrossRef]

62. Capparelli, R.; Nocerino, N.; Iannaccone, M.; Ercolini, D.; Parlato, M.; Chiara, M.; Iannelli, D. Bacteriophage therapy of Sal-monella enterica: A fresh appraisal of bacteriophage therapy. J. Infect. Dis. 2010, 201, 52-61. [CrossRef] [PubMed]

63. Capparelli, R.; Nocerino, N.; Lanzetta, R.; Silipo, A.; Amoresano, A.; Giangrande, C.; Becker, K.; Blaiotta, G.; Evidente, A.; Cimmino, A.; et al. Bacteriophage-resistant Staphylococcus aureus mutant confers broad immunity against staphylococcal infection in mice. PLoS ONE 2010, 5, e11720. [CrossRef] [PubMed]

64. León, M.; Kokkari, C.; García, K.; Castillo, D.; Katharios, P.; Bastías, R. Diversification of Vibrio anguillarum driven by the bacteriophage CHOED. Front. Microbiol. 2019, 10, 1396. [CrossRef] [PubMed]

65. Arisaka, F.; Kanamaru, S.; Leiman, P.; Rossmann, M.G. The tail lysozyme complex of bacteriophage T4. Int. J. Biochem. Cell Biol. 2003, 35, 16-21. [CrossRef]

66. Lopes, A.; Pereira, C.; Almeida, A. Sequential combined effect of phages and antibiotics on the inactivation of E. coli. Microorganisms 2018, 6, 125. [CrossRef]

67. Christiansen, R.H.; Madsen, L.; Dalsgaard, I.; Castillo, D.; Kalatzis, P.G.; Middelboe, M. Effect of bacteriophages on the growth of Flavobacterium psychrophilum and development of phage-resistant strains. Microb. Ecol. 2016, 71, 845-859. [CrossRef]

68. Kim, J.H.; Son, J.S.; Choi, Y.J.; Choresca, C.H.; Shin, S.P.; Han, J.E.; Jun, J.W.; Kang, D.H.; Oh, C.; Heo, S.J.; et al. Isolation and characterization of a lytic Myoviridae bacteriophage PAS-1 with broad infectivity in Aeromonas salmonicida. Curr. Microbiol. 2012, 64, 418-426. [CrossRef] 
69. Silva, Y.; Moreirinha, C.; Pereira, C.; Costa, L.; Rocha, R.J.M.; Cunha, Â.; Gomes, N.C.M.; Calado, R.; Almeida, A. Biological control of Aeromonas salmonicida infection in juvenile Senegalese sole (Solea senegalensis) with phage AS-A. Aquaculture 2016, 450, 225-233. [CrossRef]

70. Silva, Y.J.; Costa, L.; Pereira, C.; Mateus, C.; Cunha, Â.; Calado, R.; Gomes, N.; Pardo, M.A.; Hernandez, I.; Almeida, A. Phage therapy as an approach to prevent Vibrio anguillarum infections in fish larvae production. PLoS ONE 2014, 9, e114197. [CrossRef] [PubMed]

71. Alves, E.; Carvalho, C.M.B.; Tomé, J.P.C.; Faustino, M.A.F.; Neves, M.G.P.M.S.; Tomé, A.C.; Cavaleiro, J.A.S.; Cunha, Â.; Mendo, S.; Almeida, A. Photodynamic inactivation of recombinant bioluminescent Escherichia coli by cationic porphyrins under artificial and solar irradiation. J. Ind. Microbiol. Biotechnol. 2008, 35, 1447-1454. [CrossRef]

72. Tacão, M.; Correia, A.; Henriques, I.S. Low prevalence of carbapenem-resistant bacteria in river water: Resistance is mostly related to intrinsic mechanisms. Microb. Drug Resist. 2015, 21, 497-506. [CrossRef] [PubMed]

73. Adams, M.H. Bacteriophages; Interscience Publishers: New York, NY, USA, 1959.

74. Kutter, E. Phage host range and efficiency of plating. In Bacteriophage: Methods and Protocols; Humana Press: Totowa, NJ, USA, 2009; pp. 141-149. ISBN 978-1-58829-682-5. 